\title{
TURIZMUSFEJLESZTÉSSEL A HÁTRÁNYOS HELYZETƯ TERÜLETEK FELZÁRKÓZTATÁSÁÉRT - SALGÓTARJÁN ÉS A KARANCS-MEDVES-VIDÉK TURISZTIKAI POTENCIÁLJA
}

\author{
MOLNÁR NÓRA - EGEDY TAMÁS \\ TOURISM DEVELOPMENT FOR CATCHING UP IN DISADVANTAGED AREAS \\ - THE TOURISM POTENTIAL OF \\ SALGÓTARJÁN AND THE KARANCS-MEDVES REGION
}

\begin{abstract}
Our study presents the tourism potential of the Karancs-Medves region and the possible directions for the development of local tourism. This study seeks to explore the potential of a disadvantaged area in the increasingly problematic world of overtourism, where significant and valuable attractions exist that meet the needs of many toursitic segments. In order to explore the situation of local tourism, we provide an inventory of attractions and a SWOT analysis, as well as results of empirical studies (an online questionnaire survey and in-depth interviews) in order to explore the opinion of different stakeholders on local tourism. Developing and expanding local tourist attractions, services, accommodations, and tourism marketing activities, primarily based on natural values, is essential to making tourism play a greater role in overcoming socio-economic problems in disadvantaged areas. Better utilization of tourism potential could open the door to sustainable slow tourism, which could contribute to making the Karancs-Medves area a real alternative to the country's destinations threatened by overtourism.
\end{abstract}

Keywords: touristic potential, tourism development, geopark, Karancs-Medves area

\section{Bevezetés}

A hazai turizmus tervezésének átfogó alapdokumentációját a Nemzeti Turizmusfejlesztési Stratégia 2030 képezi, amely a hazai turizmus jövőjét érintő fejlesztések megvalósításához ad iránymutatást. A stratégia célja, hogy a hazai turizmusban látványos és eredményes fejlesztések menjenek végbe és Magyarország turizmusa a világtendenciához tudjon igazodni (NTS 2017). A stratégiában hosszú távú és jövedelmező fejlesztési irányokat jelöltek ki. A fejlesztések legfontosabb részét a turistafogadás feltételeinek minőségi javítása, az emberi erőforrás fejlesztése és az attrakciófejlesztések alkotják, amelyek a belföldi turistaforgalom növekedéséhez is hozzájárulnak. A stratégia új szemléletet alapoz meg a hazai turizmusban annak érdekében, hogy a turizmus a fenntartható gazdasági fejlődés húzóágazata legyen és a magyarországi turisztikai kínálat világszinten is közkedveltté váljon. Tanulmányunk témája ily módon szorosan kapcsolódik a Nemzeti Fejlesztési Stratégiához, s bár Nógrád megye jelenleg nem kiemelt turisztikai fejlesztési terület, a terület turisztikai potenciálja mindenképpen indokolja a turisztikai beruházásokat.

A tájképi, ipartörténeti emlékekben bővelkedő Nógrád megye jelenleg az építészeti örökségek területi elhelyezkedésének súrúsége alapján Magyarország egyik leggazdagabb megyéje. A megye az észak-magyarországi régióhoz tartozik, amely a belföldi turizmusban az ország harmadik legnépszerúbb turisztikai régiója (Tájékoztató 2015). Salgótarján és a Karancs-Medves-vidék turisztikai vonzereje ugyancsak sokszínú, a természeti táj mellett számos történelmi és kulturális értéket óriz. Ugyanakkor a korszerútlen infrastruktúra, az elhagyatott ipari területek látványa, a szolgáltatások alacsony színvonala és az 
emberek tudatában uralkodó negatív sztereotípiák a térségről egyértelmúen csökkentik a térség turisztikai vonzerejét (GELSEI S. et al. 2017). A vidék turisztikai desztinációkban, természeti, történeti emlékekben rendkívül gazdag, ezek jelentős része viszont marketing hiányában kihasználatlan, a vonzerôk kevesek számára ismertek, amiről a térségbe látogatók feltúnően alacsony száma tanúskodik. Már régóta keresik a megoldást a helyi szakemberek, hogy miként lehetne a várost és a természeti kincsekben gazdag környezetét turisztikailag felvirágoztatni, fejleszteni, turisztikai vonzerőit jobban kihasználni. Úgy gondoljuk, hogy a negatív folyamatok ellenére a lehetôségek adottak arra, hogy Salgótarján és a Karancs-Medves-vidék idegenforgalma áttörést érjen el, megerősödjön és a turizmus fejlődése pozitív jövőképet tudjon felmutatni a térség számára.

Tanulmányunk a térség turisztikai potenciálját, illetve a helyi turizmus fejlesztésének lehetséges irányait mutatja be. Fő kutatási kérdéseink a következők: Melyek Salgótarján és

a Karancs-Medves-vidék főbb turisztikai termékei? Milyen fejlődési lehetőségeket hordoz magában a térség? Melyek azok a létező és jövőbeli turisztikai fejlesztések, amelyek a gazdasági fellendüléshez hozzájárulhatnak? Hogyan lehetne a vidéket a turisták és a látogatók számára vonzóbbá tenni? A Nemzeti Turizmusfejlesztési Stratégia 2030 a jelentős turisztikai mutatószámokkal rendelkező, fejlett desztinációkat preferálja. Tanulmányunkkal megpróbálunk utána járni annak, hogy az egyre több problémát okozó overtourism világában milyen esélyekkel indulhat egy hátrányos helyzetú térség, ahol olyan jelentôs és értékes attrakciók vannak, amelyek számos keresleti szegmens igényeit kielégíthetik.

A turizmus fejlesztése jelentős szerepet játszhat a hátrányos helyzetű térségek helyzetének javításában. Ezt a lehetôséget már az 1970-es évek második felében felismerték a szakemberek (HAuENSChIELD V.-GRUB P. D. 1978; DE KADT, E. 1979), ugyanakkor a turizmus életminőségre, valamint a vidék fejlődésére gyakorolt hatásainak feltárása igazándiból az ezredforduló óta vett nagyobb lendületet a nemzetközi és hazai kutatásokban (ARCHER, B. 2005; Beckendorff, P. et al. 2009; Chaperon, S.-Bramwell, B. 2013; Salvatore, R. et al. 2018; illetve Boros L. 2002; MichalKó G. 2004). Az Észak-magyarországi régiót górcső alá vevő tanulmányok (DÁVID L. et al. 2009; PÉTER Zs. 2010) egyértelmúen arra a következtetésre jutottak, hogy nincs szoros összefüggés a kistérségek általános fejlettségi szintje és a turisztikai kereslet növekedésének dinamikája között, vagyis a hátrányos helyzetű területek is képesek lehetnek jelentős turisztikai keresletet indukálni. Ily módon a turizmus kitörési pont lehet a régió kevésbé fejlett kistérségei számára. Tanulmányunkkal tulajdonképpen ezt a korábbi kutatási eredményt próbáljuk meg alátámasztani.

\section{Az Észak-magyarországi régió és Nógrád megye}

A Karancs-Medves-vidék és Salgótarján az Észak-magyarországi régióban található. Az Észak-magyarországi régió Magyarország 8 tervezési-statisztikai régiójának egyike, amelyhez Borsod-Abaúj-Zemplén, Heves és Nógrád megye tartozik. A régió területe $13429 \mathrm{~km}^{2}$, lakónépessége 1126360 fő volt 2019-ben. Az Észak-magyarországi régió a 19-20. században az ország nehézipari központja volt, elsősorban a bányászat és a kohászat játszott fontos szerepet a térségben. A rendszerváltozás a gazdaság drasztikus visszaesését hozta magával, ami az ipar leépülését, a lakosság életszínvonalának csökkenését és magas munkanélküliséget eredményezett. A régió napjainkban is jelentős társadalmi és gazdasági nehézségekkel küzd. Az egy főre jutó GDP az országos átlagnak mindössze $69 \%$-a, amellyel a régiók sorában csak a hatodik helyet foglalja el és csak Dél-Dunántúlt (68,8\%), illetve az Észak-Alföldet (64,2\%) előzi meg. Természeti adottságai alapján az ország egyik legváltozatosabb régiója (PISKóTi I. 2006). 
Nógrád megye az ország egyik legkisebb megyéje, területe 2544 km² , lakónépessége 189304 fő volt 2019-ben. Az egy fơre jutó GDP alapján Nógrád az ország legfejletlenebb megyéje: az egy főre jutó bruttó hazai termék az országos átlag 44,5\%-a, s évek óta az utolsó helyen áll a megyék rangsorában. A természetes népesség fogyása és a munkanélküliségi ráta $(7,5 \%)$ is meghaladja az országos átlagot. Mivel Nógrád megye tipikus aprófalvas terület, a városi népesség aránya $(41,9 \%)$ jóval alacsonyabb az országos átlagnál (70,4\%). A megye gazdaságában az ipar az országos viszonyoknál fontosabb szerepet játszik, 2013-ban az ipari és építőipari tevékenységek bruttó hozzáadott értéke 32,5\% volt (KSH 2014). Fontos megjegyezni, hogy a megye termelési értékeinek döntő többsége a salgótarjáni kistérségból származik, így a megyén belül jelentős a társadalmi-gazdasági polarizáció. Nógrád megye székhelye és legnagyobb városa Salgótarján megyei jogú város (2. kép). A magyar-szlovák határhoz közel, a Karancs, a Medves és a Cserhát hegységek találkozásánál fekszik, területe 98 km², lakónépessége 33579 fő volt 2019-ben (KSH 2019).

Észak-Magyarország elsősorban a belföldi turizmus kedvelt célterülete. A vendégek száma alapján megelőzi Észak- és Dél-Alföldet, valamint a Dél-Dunántúlt, a vendégéjszakák száma alapján pedig a két alföldi régiót. A vendégforgalom megoszlása a régión belül viszont rendkívül aránytalan. Az 1. táblázat jól érzékelteti Nógrád megye alárendelt szerepét a régió, illetve az ország turizmusában, az 1. ábra pedig jól szemlélteti a megye egyre kedvezőtlenebbé váló pozícióját a régió másik két megyéjéhez képest.

Nógrád megye a kereskedelmi szálláshelyeken eltöltött vendégéjszakák alapján a megyék sorrendjében az utolsó helyen állt 2018-ban. A megye csupán 7\%-kal részesedett az észak-magyarországi régió vendégforgalmából, az országos vendégforgalomnak pedig alig 0,7\%-át adta (1. táblázat). Habár a kereskedelmi szálláshelyeken regisztrált vendégek és vendégéjszakák száma 2012 óta folyamatosan nő, a mutatók országos és régiós összehasonlításban továbbra is rendkívül alacsonyak. A régión belül a vendégforgalomban tapasztalható olló Nógrád megye, valamint Borsod-Abaúj és Heves megyék között egyre nyílik (1.ábra).

1. táblázat - Table 1

A kereskedelmi szálláshelyek vendégforgalma az Észak-magyarországi régióban

Number of guests and guest nights

in commercial accommodations in Northern Hungary

\begin{tabular}{lrrrr}
\hline & $\mathbf{2 0 1 5}$ & $\mathbf{2 0 1 6}$ & $\mathbf{2 0 1 7}$ & $\mathbf{2 0 1 8}$ \\
& \multicolumn{4}{c}{ Vendégek száma, fó } \\
\hline Borsod-Abaúj-Zemplén & 383119 & 417691 & 453759 & 488933 \\
Heves & 571926 & 582765 & 630922 & 619918 \\
Nógrád & 55492 & 64852 & 74117 & 83732 \\
Észak-Magyarország & $\mathbf{1 0 1 0 5 3 7}$ & $\mathbf{1 0 6 5 3 0 8}$ & $\mathbf{1 1 5 8 7 9 8}$ & $\mathbf{1 1 9 2 5 8 3}$ \\
\hline \multicolumn{4}{c}{ Vendégéjszakák száma, db } \\
\hline Borsod-Abaúj-Zemplén & 879853 & 981261 & 1045820 & 1136857 \\
Heves & 1285801 & 1310595 & 1432262 & 1389499 \\
Nógrád & 130852 & 133122 & 162938 & 187501 \\
Észak-Magyarország & $\mathbf{2 2 9 6 5 0 6}$ & $\mathbf{2 4 2 4 9 7 8}$ & $\mathbf{2 6 4 1 0 2 0}$ & $\mathbf{2 7 1 3 8 5 7}$ \\
\hline
\end{tabular}

Forrás: KSH tájékoztatási adatbázis alapján saját szerkesztés 


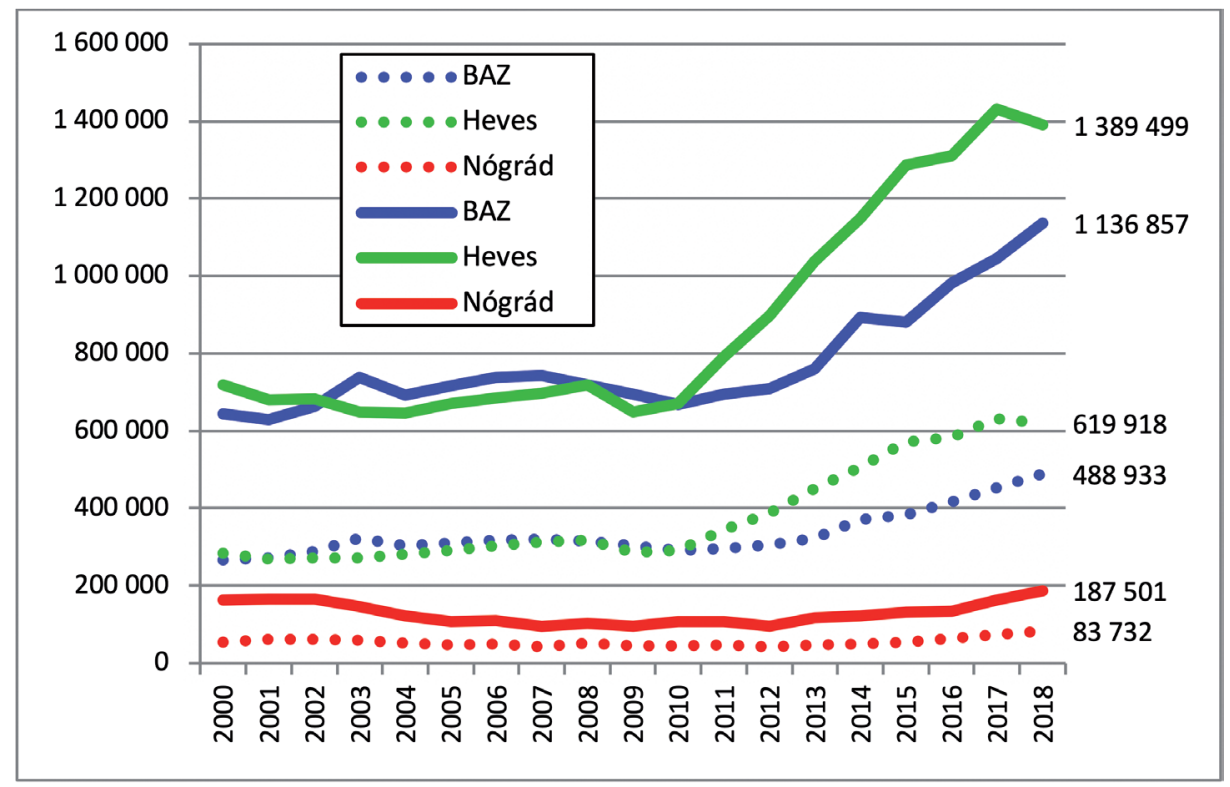

1. ábra Vendégek és vendégéjszakák száma az Észak-magyarországi régió megyéinek kereskedelmi szálláshelyein (2000-2018)

Figure 1 Number of guests and guest nights in commercial accommodations in Northern Hungary by counties (2000-2018) Jelmagyarázat: Szaggatott vonal: vendégek száma; Folyamatos vonal: vendégéjszakák száma. Legend: dashed line - number of guests; continuous line - number of guest nights

Forrás: KSH tájékoztatási adatbázis alapján saját szerkesztés / Source: based on the dataset of CSO Hungary

Az adatok arról tanúskodnak, hogy az Észak-magyarországi régió, azon belül különösen Nógrád megye egyelőre kiaknázatlan lehetôsége a turizmus. Ebben a régióban található a Világörökségi listán szereplő Hollókői Ófalu és táji környezete, az Aggteleki-karsztvidék, valamint a Tokaji történelmi borvidék és kultúrtáj. Az UNESCO által nyilvántartott világörökségi lista mellett külön jegyzék szól a szellemi és kulturális örökségekről. Ennek része a matyó és palóc népmúvészet és népi hagyományok. A régió bővelkedik termálforrásokban és fürdőkben, közülük kiemelhető a miskolctapolcai barlangfürdő. A Mátra vonulatai kedveznek a téli sportok és a túrázók kedvelőinek, valamint a friss hegyi levegő a gyógyüdülést is szolgálja. A vonzerők (attrakciók) a turizmus fontos részét képezik, a turistákat nagymértékben motiválják. Az Észak-magyarországi Régió Turizmusfejlesztési Stratégiájának kidolgozása során a szakértők összesen 4670 vonzerôelemet azonosítottak, amelyekből 905 Nógrád megyében található (PISKóTi I. 2006). Ez arra utal, hogy a megye turisztikai potenciálja lényegesen nagyobb, mint amit tényleges részesedése mutat a turisztikai mérőszámokból.

\section{A Karancs-Medves-vidék turizmusföldrajza}

\section{A természeti környezet értékei}

\section{A terület kialakulása és földtörténeti múltja}

A terület két alaphegységi pásztája valószínúleg tengeri és lagúnás sekélytengeri környezetben alakultak ki 250-350 millió évvel ezelőtt, amelyek alapját képezték a későbbi oligocén kori tengernek. A harmadidőszakban a medencejellegú terület az oligocén és 
a miocén között folyamatosan süllyedt és töltődött fel finomabb szemú tengeri üledékekkel (pl. kiscelli agyag, szécsényi slír, pétervásárai homokkő, zagyvapálfalvai tarkaagyag). A miocén ottnangi korszakában 19-20 millió évvel ezelőtt vulkáni tevékenység vette kezdetét a területen, ekkor rakódtak le a piroklasztitos riolittufa rétegek. A vulkáni múködést követően folytatódott a szárazföldi, folyóvízi-deltabeli, ártéri-mocsári üledékek képződése kavicsos durvaszemú homok és tarkaagyagok formájában. A nedves-szubtrópusi viszonyok egyúttal kedveztek a szénképződésnek, ekkor alakult ki a salgótarjáni barnakőszén formáció. A szénbányászat a 19-20. században meghatározó jelentőségú volt a környék gazdaságában és megalapozta a kohászat megtelepedését Salgótarjánban.

A felerősödő szerkezeti mozgások következtében a miocén badeni korszakában jelentős andezitvulkánosság indult meg (Karancsi Andezit Formáció), amely létrehozta a Karancs szubvulkáni lakkolitját. A szerkezeti mozgások a pliocén és pleisztocén időszakot is végigkísérték, amelynek következtében 8 millió és 400000 ezer év között hat fázisban bazaltvulkánosság vált meghatározóvá a területen. A második szakaszban, 5,5-3,7 millió évvel ezelőtt keletkeztek a tanulmányunkban is említett Salgó, Kis-Salgó (más néven Boszorkány-kő) és Somos-kő (2.ábra). A vulkáni formák napjainkra részben vagy teljesen lepusztultak és csak a vulkáni csatornában kihưlt, többé-kevésbé hengeres alakban megmerevedett lávatömegeik, az ún. csatornakitöltések (népszerú nevén bazaltzuhatagok) bukkannak felszínre. A harmadik és negyedik fázisban (2,9-2,6 millió, illetve 1,6-1,3 millió évvel ezelőtt) keletkezett a Medves-fennsík $12 \mathrm{~km}^{2}$-es bazalttakarója, amely a Medves tűzhányójából felszínre törő két, hatalmas, sűrű lávafolyás maradványa. A Medves-fennsík a magyar-szlovák országhatáron húzódik, Európa legnagyobb és legmagasabban fekvő vulkanikus eredetű bazaltfennsíkja. A vulkanikus kúpokban bővelkedő táj teljes területéből 7,8 km² fekszik Magyarország terültén (web1). A negyedidőszakban a Karancs-Medves területe jelentősen, mintegy 300 méterrel megemelkedett, a folyamatos éghajlatváltozások felszínformáló hatására a bevágódó völgyeket fiatal törmelékes üledékek (kavics, homok, agyag, bazaltos törmelék), deluviális lejtôtörmelékek, proluviális hordalékkúpok agyagos-köves üledéke, valamint a holocénban ártéri agyag és agyagos-kavicsos homok töltötték ki (PRAKFALVI P. et al. 2007).

\section{A Novohrad-Nógárd geopark}

Egy geopark mint intézmény az élettelen természeti értékekre fókuszál, a kiemelkedő jelentőségû kutatási és oktatási, vagy esztétikai értékkel bíró földtani és felszínalaktani értékek, geológiai örökség bemutatására helyezi a hangsúlyt. Kiemelt szerepet játszik múködésében a geoturizmus támogatása, amely hozzájárulhat egy térség helyi gazdaságának a fejlődéséhez, illetve a helyben élők környezetének és életminőségének a javulásához. A geoparkok múködése a helyi közösségek és szervezetek együttmúködésén alapul, s kiemelt szempont a földtudományi értékek bevonása a környezeti nevelésbe, oktatásba és kutatásba (web2).

Az UNESCO Földtudományi Tagozata 1997-ben hirdette meg geopark programját. A szervezet támogatásával 2004-ben megalapították a Globális Geopark Hálózatot, amelynek tagjai 2015 óta UNESCO Globális Geoparkokként múködnek. Jelenleg 41 országban 147 globális geopark múködik. Az intézményesülés keretében 2000-ben alakult meg az Európai Geopark Hálózat, amely jelenleg 26 országból 75 geoparkot fog össze és egyben koordinálja az európai globális geoparkok múködését is. Magyarországon jelenleg két geopark múködik: a Novohrad-Nógrád Geopark 2010 márciusa, a Bakony-Balaton Geopark pedig 2012 szeptembere óta tagja az Európai és a Globális Geopark Hálózatnak.

A Novohrad-Nógrád Geopark a világ első határon átnyúló geoparkjaként alakult 2008ban és meghatározó szerepet játszik a térség turizmusában. A palóc vidék földtani, ökológiai, történelmi és kulturális értékeit mutatja be 64 magyarországi és 28 szlovákiai településen. A geopark teljes területe $1619 \mathrm{~km}^{2}$, amelyből $1284 \mathrm{~km}^{2}$ Magyarországon fekszik. 


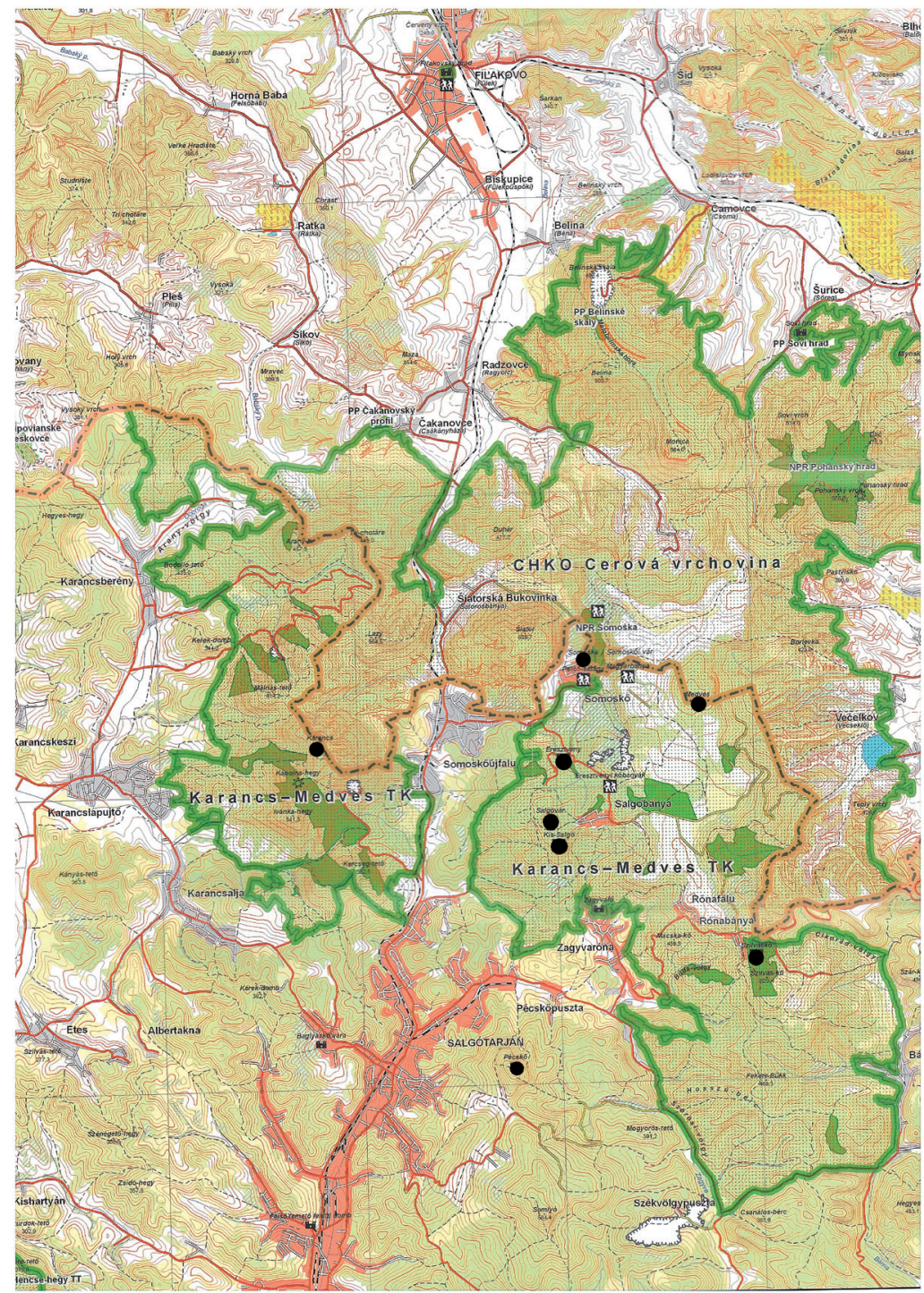

2.ábra A Karancs-Medves-vidék áttekintő térképe

Figure 2 Overview map of Karancs-Medves region

Forrás: Kiss G. et al. 2007 térképmelléklete alapján / Source: based on Kiss G. et al. 2007

A geopark területén 200 millió év történéseit tekinthetjük át a triász rétegektől a 24 millió éves sekélytengeri üledékeken át a holocén-pleisztocénban bevágódott szurdokokig.

A térség turizmusában kiemelt szerepe van a világhírú őslénytani lelőhelynek, az Ipolytarnóci Ôsmaradványok Természetvédelmi Területnek. Ipolytarnóc Nógrád megye legészakibb települése, az Ipoly partján, a szlovák határhoz közel fekszik. 1995 óta Európa Diplomás bemutatóhely és jelenleg szerepel az UNESCO világörökségi javaslati listáján is. Ipolytarnóc környékét a miocén korban tenger borította, amelyben különböző rétegződésú homokkő rakódott le. Ezen rétegekben tengeri süntüskéket, spongia tűket és cápafo- 
gakat találtak. A sekély tengeröböl elzáródott, s a pangó vízbe jelentős mennyiségû törmelékes üledék került. A kavicsrétegek metamorf és vulkáni kőzetek, valamint homokkő lepusztulási darabjaival keverednek. A korábbi tengeri környezetet néhány millió évre szelíd feltöltődésú folyóvízi környezet váltotta fel, amelyben szürke homokkő rakódott le. Ez a szürke homokkő rejti a világhírű lábnyomokat, amelynek fennmaradásához szükség volt arra, hogy a területet hirtelen nagy mennyiségű vulkáni hamu fedje be. A vulkánkitörés 17,4 millió évvel ezelőtt kezdődött, s az általa kibocsátott portufa hamu ôrizte meg a Bestiopeda, Carnivoripeda, Mustelipeda, Rhinoceripeda, Megapecoripeda és Pecoripeda lábnyomokat (SzTANó O.-HARANGi Sz. 2010; HÁGEN et al. 2013). Az egész ősi élóhelyet riolittufa ár fedte le, megőrizve a homokkőbe ékelődő lábnyomokat és növényi maradványokat. A terület tudományos kutatása 1836 óta folyik és öt jelentôs idôszakot foglal magába: 1836-ban találták meg a híres megkövesedett fatörzset, 1890-ben fedezték fel a lábnyomos homokkövet, amelyet 1928-ban tovább kutattak és tártak fel, 1937-ben tárták fel az orrszarvú lábnyomokat, 1960 ragadozó és masztodon nyomokat találtak, 1979-tôl pedig elkezdődtek a természetvédelmi beruházások, amelynek keretében az 1980-as évek első felében tudományos igényú kipreparálásokat végeztek. A 17-20 millió évvel ezelőtti világból már közel 3000 lábnyom került elő, emellett 8 millió éves megkövesedett bükkábrányi ősfenyő törzseket is kiállítottak. A terület a Bükki Nemzeti Park Igazgatóságának a kezelése alatt áll, a térség egyik legkedveltebb turisztikai célpontja, a geoturizmus kedvelt kirándulóhelye. A természetvédelmi területen több tanösvény is van, mint például geológiai, kőzetparki, biológai, kőszikla ösvény, amelyek a földtörténeti múlt emlékeit mutatják be (1. kép). A geoparkban 3 további látógatócentrum várja a turistákat: 1) a Geocsodák Háza Salgóbányán, ahol interaktív bemutatók kal és előadásokkal várják a látogatókat, emellett több mint 30 túraútvonalat kínál a természetjáróknak (SzEPESSY G. 2014); 2) az Eresztvényi Látogatóközpont, ahonnan vezetett túrák indulnak (Eresztvény a Medves kapuja, így fontos kirándulóövezetben fekszik), ismeretterjesztô elóadásokat lehet meghallgatni a környék nevezetességeiről és madármegfigyelésen lehet részt venni; 3) a Nógrádi Turisztikai

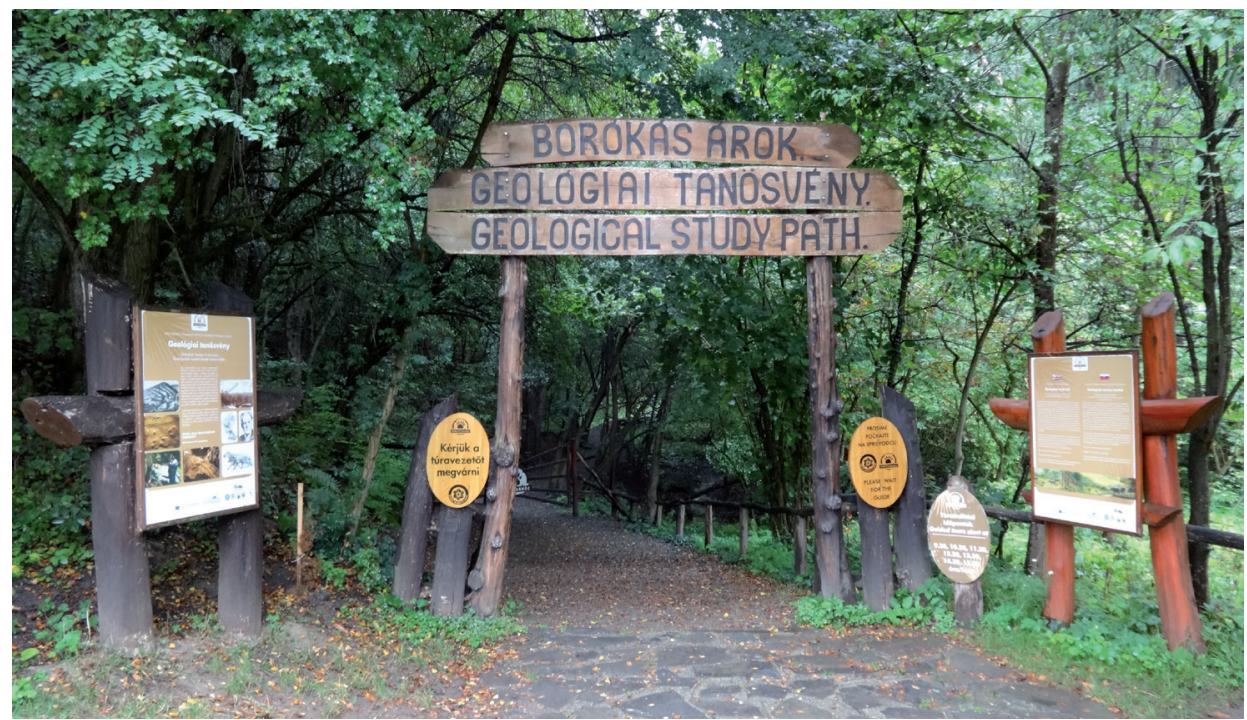

1. kép Ipolytarnóc - A geológiai tanösvény bejárata Photo 1 Ipolytarnóc - Entrance of the geological study path Forrás/Source: T. EGEDY 
Információs Központ, amely a Füleki Vármúzeum hatáskörében múködő információs iroda, fó feladatai a Besztercebányai körzet déli és a Nógrád megye északi részével kapcsolatos turisztikai információk gyújtése és terjesztése, reklám- és marketingszolgáltatások, valamint sport-, kulturális és egyéb közösségi rendezvények szervezése.

\section{Egyéb jelentős természeti értékek}

Salgótarján vidékének egyedülálló természeti értéke a Karancs-Medves Tájvédelmi Körzet, amely a Bükki Nemzeti Park Igazgatósága alá tartozik. Területe 6709 hektár, amelyből 447 hektár szigorúan védett (KISS G. et al. 2007).

A térség talán legismertebb geológiai képződménye a somoskői vár alatt, szlovák oldalon található bazaltzuhatag, amely tűzhányóból kiömlött láva lassú kihúlésének eredménye. Geoturisztikai szempontból említésre méltók a bazaltömlés 15-20 cm széles öt-és hatszögletú íves oszlopai (2. kép).

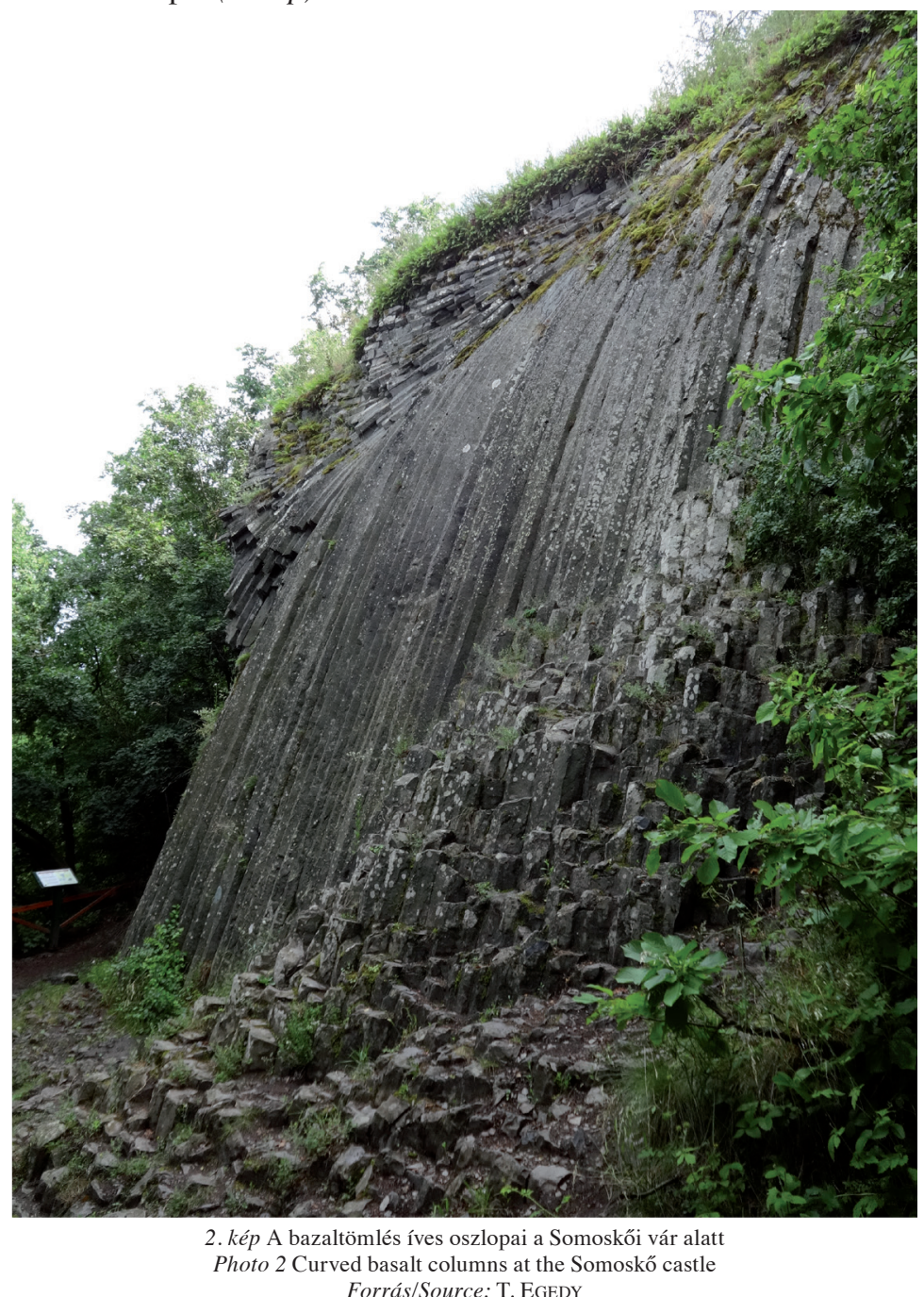


Salgótarján közelében található legmagasabb csúcs a „Palóc Olimposznak” nevezett 729 m magas Karancs-hegy. A Karancs-Medves-vidék legmagasabb pontján található a 22 m magas, acélszerkezetes Karancs-kilátó. A kilátó 1989-ben készült el, 2001-ben felújították, újrafestették. A kilátóig ösvény, meredek turistaút halad. A csúcsot elérve lenyưgöző körpanoráma nyílik a salgói és a somoskői várra, a Medvesre, a Magas-Tátrára, a Mátrára, de még a Dunakanyar is tisztán látható. A hegytetôn élő webkamera is található, ami az egyik leglátogatottabb internetes tartalom Salgótarjánban (web3).

A Salgó várromtól néhány perc sétára, vadregényes fenyőerdőn keresztül érhető el a különleges formájú Boszorkány-kő (Kis-Salgó) (3. kép). A legenda szerint ezen a területen szabadultak meg a boszorkánysággal megbélyegzett nőktől. A panoráma innen is lenyưgöző, Salgó vára és a Medves fennsíkja is tökéletesen kivehető. A Boszorkány-kő felé vezető kitáblázott geológiai tanösvény a szikla változatos vulkáni kőzeteirôl és a geológiai történetéról ad tájékoztatást.

A Szilváskő kedvelt célpontja a kirándulóknak, a hegyen 2 kilométeres geológiai tanösvény mutatja be a vulkáni múködést és a terület földtani értékeit.

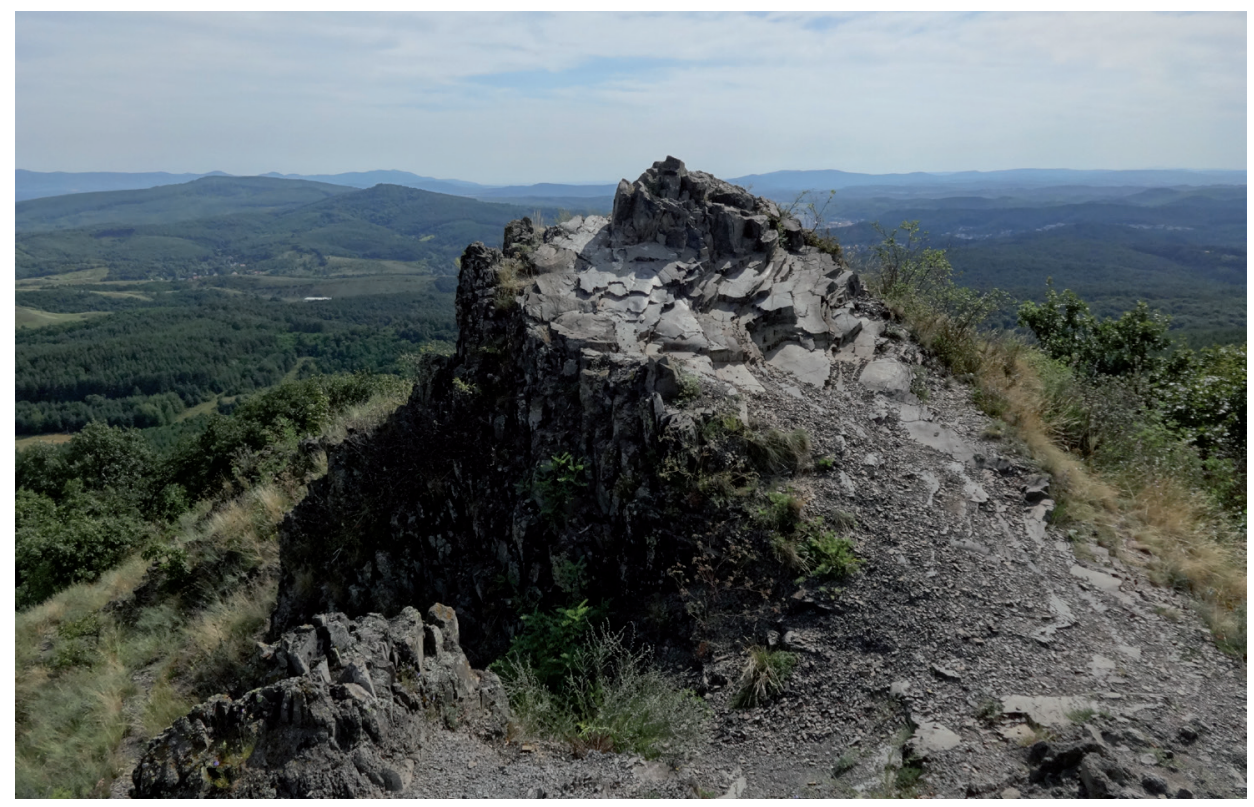

3. kép A Boszorkány-kő csúcsa kilátással Salgótarjánra

Photo 3 Boszorkány-kő with scenic view on Salgótarján

Forrás/Source: T. EGEDY

Nógrád megyében a legmagasabb az erdőterületek aránya Magyarországon (40\%), emellett a védett természeti területek száma is kiemelkedő. A növényvilág ritkaságai közé tartoznak a bársonyos kakukkszegfü, a dunai csillagvirág, a kardos madársisak és az ikrás fogasír. Az állatvilág különleges képviselői a darázsölyv, a császármadár és a fehérhátú fakopáncs.

A környék természeti értékeinek felfedezésében egyre fontosabb szerepet játszik a geocaching. A szabadidős tevékenység lényege, hogy valamilyen felfedezésre érdemesnek tartott helyszínen megfelelő módon elrejtenek egy jól zárható kisebb ládát. A rejtekhely pontos GPS koordinátáit rögzítik és feltöltik a geocaching.hu weboldalra, ahonnan más 
vállalkozó kedvú játékosok, túrázók megkereshetik a helyet. A geocaching lényegében egy természetbarát játék, amely összefügg a turizmussal és az ismeretterjesztéssel.

\section{A társadalmi-gazdasági környezet értékei}

\section{Ipartörténeti értékek}

Salgótarján és tágabb környezete kiemelkedő ipartörténeti múlttal rendelkezik (HoRvÁTH G. 2009). A területen jelentős barnaszénbányák múködtek a 19. és 20. században. Ennek egyik szimbolikus, legismertebb helyszíne a József lejtősakna volt, ahol 1879 és 1905 között, illetve 1937 és 1951 között folyt a barnaszén kitermelése. A József-akna eredeti formában fennmaradt vágatrendszerében ma bányamúzeum múködik, amelyet 1965-ben nyitottak meg Európa második, Magyarország első földalatti bányamúzeumaként (4. kép). Járatának hossza 280 m hosszú, itt tekinthetjük meg az egykori szénbányászat eszközeit, technológiáit és a fejtési munkálatokat. A múzeum területét 1980-ban ipari múemlékké nyilvánították, 2005-ben pedig felújítási munkálatok folytak, s az emlékhely újabb földalatti kiállítással bővült. A bányamúzeumot 2015-tôl a Dornyay Béla Múzeum üzemelteti. A látogatók száma évról évre emelkedik, 2017-ben 16287 fő látogatta meg a salgótarjáni Bányamúzeumot (Salgótarján Helyi TDM Közhasznú Egyesület). A bányamúzeum sikere ellenére nem mehetünk el szó nélkül amellett, hogy a bányászati múlt kiaknázása sokkal nagyobb lehetőségeket hordozna magában, a bányászati emlékek geoturisztikai potenciálja nagy (HoRvÁTH G. et al. 2012), a terület ezen adottsága többnyire mégis kihasználatlan.

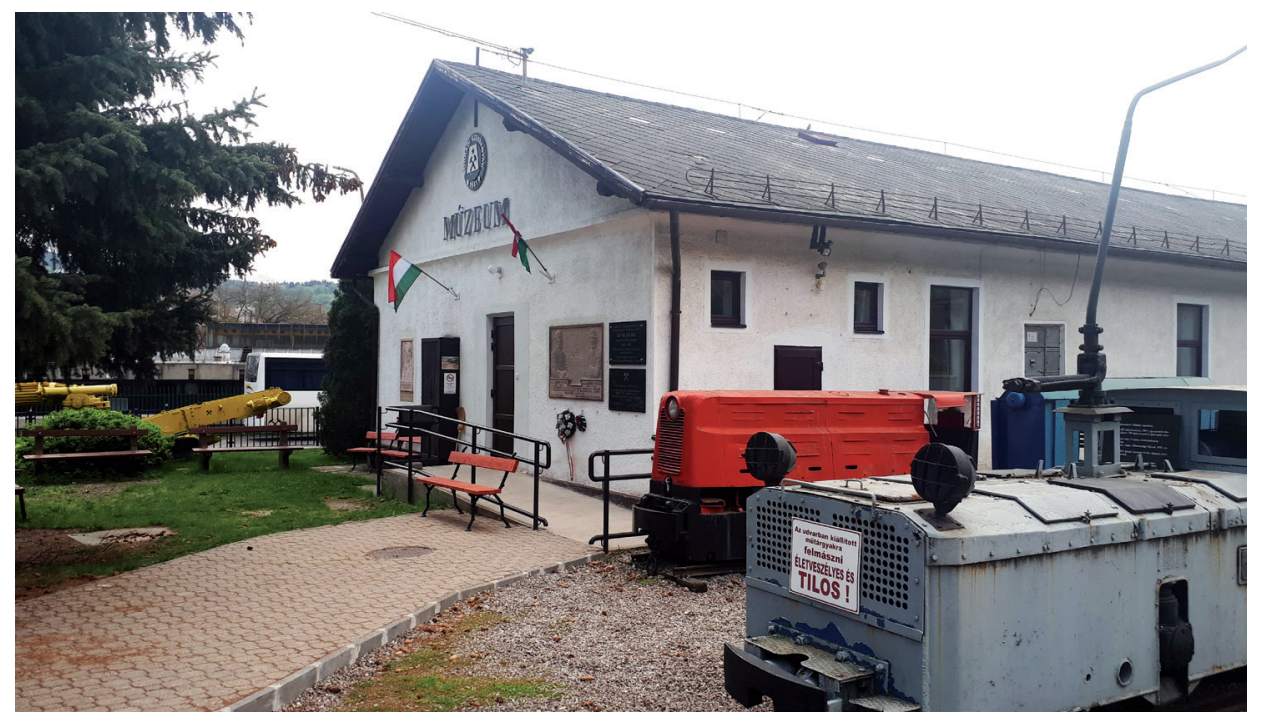

4. kép A salgótarjáni Bányamúzeum épülete

Photo 4 Building of the mining museum in Salgótarján

Forrás/Source: N. MolNÁR

Kulturális (történelmi, irodalmi, néprajzi) értékek

Salgótarján környékén a Karancs-Medves-vidék vulkáni kúpjain több vár is található. Somoskő a szlovák-magyar államhatáron fekszik, a település még Magyarországon van, viszont a vulkáni csúcson található várrom már Szlovákia része (5. kép). Az 1840-es évek idején Somoskőben járt Petőfi Sándor, a vár alatt található egy kis kunyhó, amely a költő 
egykori látogatásának emlékét őrzi. Szabadon látogatható a vár alatti Petőfi-emlékpark, ahol a 13 aradi vértanú dombornyomású arcképe és gróf Batthyány Lajos miniszterelnök mellszobra tekinthető meg. Somoskő vára a trianoni békeszerződés idején is fontos szerepet játszott a történelem során. A békeszerződés értelmében a magyar lakta Somoskőt az akkori Csehszlovákiához csatolták. A határrendező bizottság egyik angol tisztje azonban váratlanul megbetegedett. Óriási véletlen, hogy kezelőorvosa Magyarország egyik legjobb fül-orr gégésze, orvosprofesszora Dr. Krepuska Géza volt, akinek hatalmas birtokai és bányái voltak Somoskő területén. Miután meggyógyította betegségétől a tisztet, hálából a határmegállapító bizottság 1924. február 15-én visszacsatolta Magyarországhoz a települést, a vár azonban a határon túl maradt. Ezt a napot a helyiek minden évben a „Hazatérés Napjaként" tartják számon.

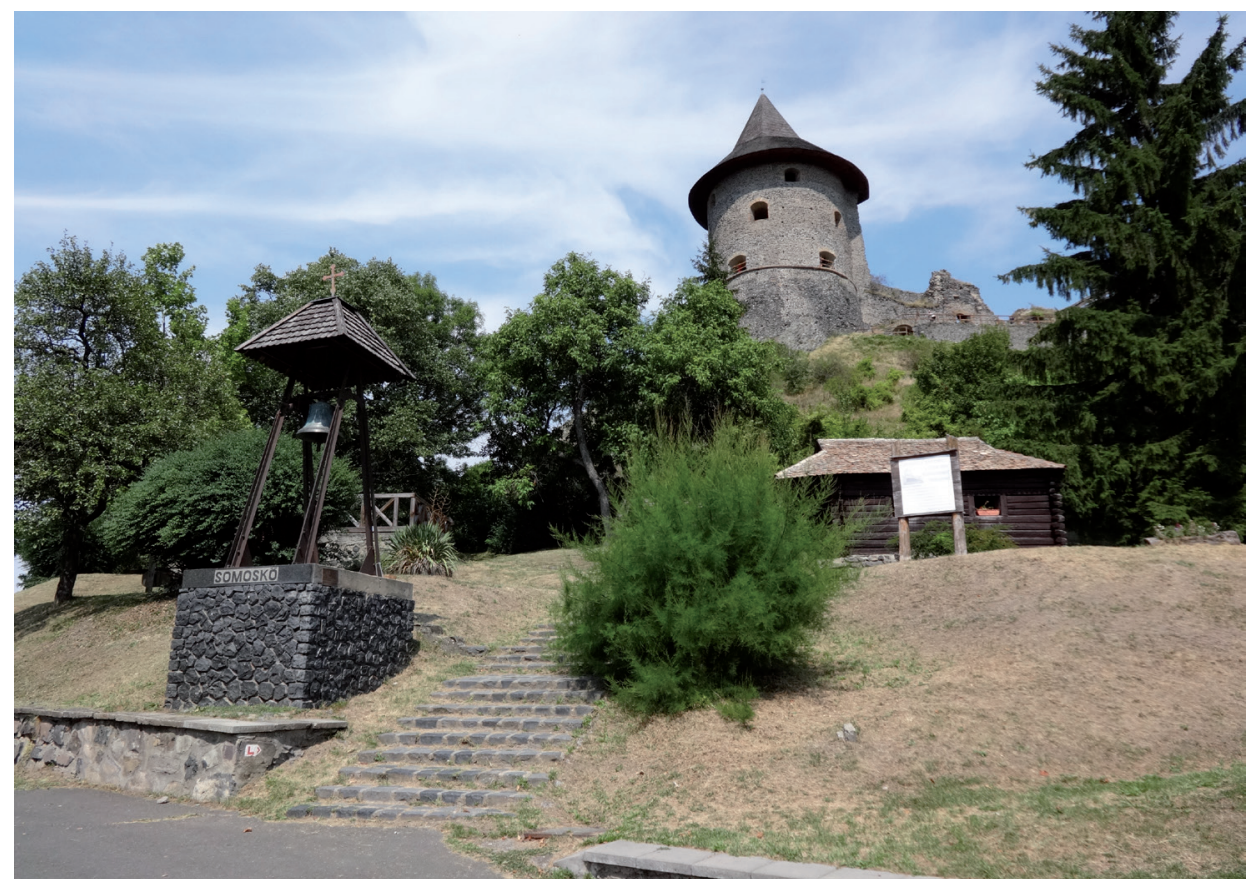

5. kép A Somoskői vár

Photo 5 The castle of Somoskő

Forrás/Source: T. EGEDY

A várlátogatás mellett a Somoskői Kirándulóközpont is csalogatja a turistákat, 2016ban elnyerte a Hónap Turistaháza címet. A kirándulóközpont szolgáltatásai közé tartoznak többek között a Vadaspark üzemeltetése, kisállat simogatók, túrák és rendezvények szervezése, valamint 19 fó elhelyezésére biztosít Salgó várára néző panorámás szálláshelyet. A kirándulóközpont közvetlen szomszédságában található a Bazalt Panzió is, amely elszállásolásra nyújt lehetőséget a festői szépségú vár alatt. A panzióban a Salgótarjáni Ugrógála cipőmúzeuma is megtalálható, ahol világhírú sportolók által dedikált lábbelik sorakoznak.

A környék fontos turisztikai attrakciója a Salgóbánya település felett 625 m magas vulkáni csúcson álló Salgó vára a 13. századból, amelyrôl részben Salgótarján kapta a nevét. Petőfi Sándor Salgó várát is felkereste, itt született Salgó címú verse. A költő látogatását emléktábla őrzi a vár falában (6. kép). 


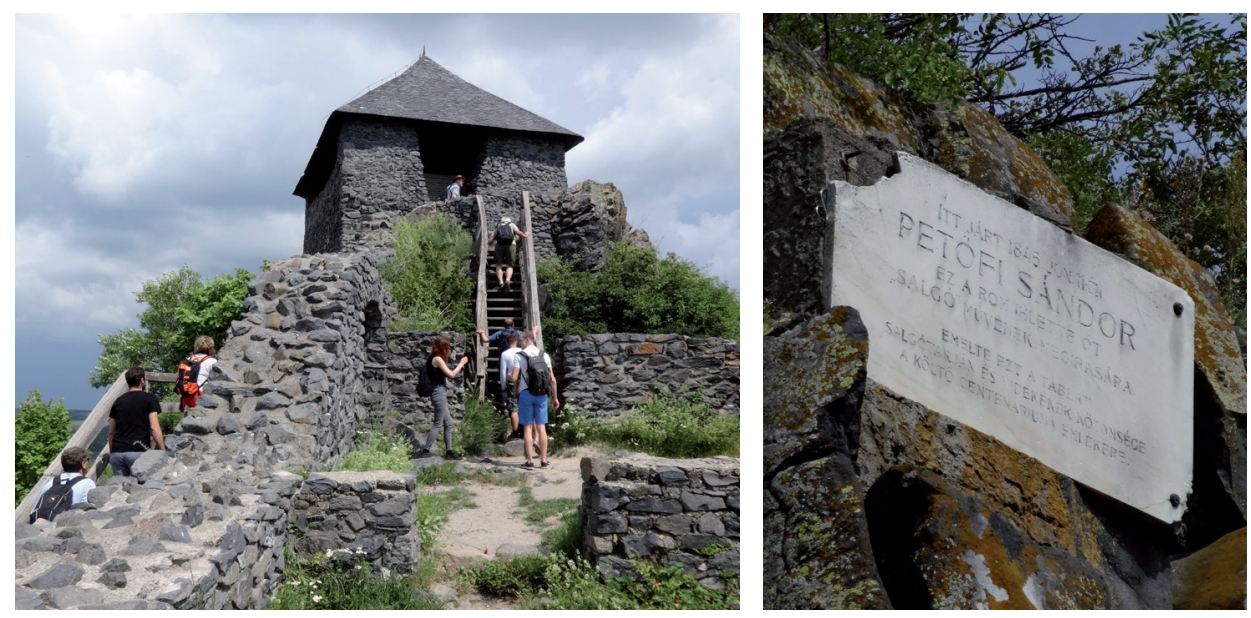

6. kép Salgó vára a Petôfi emléktáblával

Photo 6 The castle of Salgó with the Petôfi memorial plaque Forrás/Source: T. EGEDY

Salgótarján központjában található a Dornyay Béla Múzeum, amely széles körú állandó és időszakos kiállításokkal rendelkezik. A múzeum névadója Dornyay Béla, középiskolai tanár volt, ő kezdeményezte az első salgótarjáni múzeum létrehozását. A múzeum állandó kiállításai között szerepel a salgótarjáni üveggyártás bemutatása, Nógrád megye történeti áttekintése és a képtár. Számos emléket őriz Madách Imre és Mikszáth Kálmán munkásságából, valamint gazdag további történeti, régészeti, néprajzi, irodalomtörténeti, képzőmúvészeti gyújteményekben. A Dornyay Béla Múzeum 2006-ban múemléki védettséget is kapott (web4).

A Novohrad-Nógrád Geopark Eresztvényi Látógatóközpontjának közelében található a Dornyay Turistaház, amely mostanság romokban, elhagyatottan áll. A második világháború idején katonák és sebesültek számára nyújtott menedéket. Az egykori sípálya mellett lévő turistaház később panzióként és étteremként is szolgált és igen kedvelt volt nemcsak az itt megszálló vendégek, hanem a salgótarjáni lakosság körében is. A sípálya megszúnésével az épület múködtetése nehézkessé vált, így bezárt. Tervek, ötletek, elképzelések születtek a felújítással kapcsolatban, hiszen felújítva nagyszerú szálláshely lehetne most is, de egyelőre ezeknek sajnos még nyomuk sincs (web5).

\section{A kutatási terïlet SWOT-elemzése}

A kutatási terület helyzetének áttekintésére SWOT-analízist készítettünk, amely jól összefoglalja a Karancs-Medves-vidék és Salgótarján társadalmi-gazdasági adottságait (2. táblázat).

Az elemzésből levonható az a következtetés, miszerint Salgótarján és a Karancs-Medvesvidék egyértelmú erőssége a turisztikai adottságokban való gazdagsága, a természeti- és kultúrtáj jelentős turisztikai termékkínálattal. Azonban a térség turizmusát vizsgálva számba kell venni a gyengeségeket is, amelyek akadályozzák a vidék idegenforgalmának javulását. Ide soroltuk a fejletlen gazdasági helyzetet, azon belül a nem megfelelő infrastruktúrát, turizmusmarketinget, a színvonalas rendezvények és programok hiányát. Az alacsony tartózkodási idő egyik fő okozója az alacsony számú és színvonalú szállás- és vendéglátóhely, amely a térség turizmusát erőteljesen gyengíti. A vizsgálat viszont rámutat azokra a lehetőségekre is, amelyek segíthetik a térség turisztikai fellendítését. Felmerült, 
Salgótarján és a Karancs-Medves-vidék SWOT-analízise

SWOT analysis of the Karancs-Medves region

\begin{tabular}{|c|c|}
\hline Erösségek & Gyengeségek \\
\hline $\begin{array}{l}\text { kedvező földrajzi és logisztikai helyzet } \\
\text { változatos tájkép, nagy kiterjedésú erdőség } \\
\text { kiváló természeti és turisztikai adottságok } \\
\text { nagyszámú védett természeti terület } \\
\text { gazdag vonzerôleltár } \\
\text { bányászati örökség, jelentős ipari múlt } \\
\text { vonzó kultúrtáj jelentős történeti múlttal } \\
\text { erős aktív turizmus } \\
\text { közigazgatási és hivatali tapasztalatok } \\
\text { kedvező humán és szellemi tőke }\end{array}$ & $\begin{array}{l}\text { társadalmi-gazdasági nehézségek a területen } \\
\text { tókeerós gazdasági szereplők és vállalkozá- } \\
\text { sok hiánya } \\
\text { fejletlen infrastruktúra } \\
\text { tartósan magas munkanélküliség } \\
\text { alacsony életszínvonal } \\
\text { nem megfelelő turizmusmarketing } \\
\text { rendezvények, programok hiánya } \\
\text { alacsony számú és színvonalú szálláshely- és } \\
\text { vendéglátóhely } \\
\text { alacsony tartózkodási idő } \\
\text { környezeti problémák, tájegradáció } \\
\text { leromlott állapotú ipari- és rozsdaterületek }\end{array}$ \\
\hline Lehetőségek & Veszélyek \\
\hline $\begin{array}{l}\text { turisztikai termékek iránti keresletnövekedés } \\
\text { kedvező földrajzi helyzetből adódó elónyök } \\
\text { önkormányzattal és civil szervezetekkel } \\
\text { szorosabb együttmúködés } \\
\text { ökoturizmus fejlesztése, fellendülése } \\
\text { vidék- és térségfejlesztési pályázatokban való } \\
\text { részvétel } \\
\text { ipari park lehetőségeinek jobb kihasználása } \\
\text { vállalkozások bevonzása a területre } \\
\text { határon túli kapcsolatok erôsítése }\end{array}$ & $\begin{array}{l}\text { a régió társadalmi-gazdasági helyzete tovább } \\
\text { romlik } \\
\text { ipar hanyatlása folytatódik } \\
\text { munkanélküliség állandósul } \\
\text { népesség elvándorlása } \\
\text { térséget érintő turisztikai célú fejlesztések } \\
\text { elmaradása } \\
\text { környezet állapotának romlása }\end{array}$ \\
\hline
\end{tabular}

Forrás: CsüllöG G.-HoRváth G. 2010 alapján saját szerkesztés

hogy a térség számára a kedvező földrajzi helyzetéből adódóan (Budapest közelsége, országhatár) számos lehetőség nyílik a turizmus fejlesztésére. Ezen kívül a turisztikai termékek iránti keresletnövekedés, a helyi önkormányzattal való szorosabb együttmúködés, valamint a vidék-és térségfejlesztési támogatások is alapját képezhetik az esetleges jövőbeli fejlesztési lehetőségeknek. A térség legfontosabb turisztikai kínálata az ökoturizmusban és az aktív turizmusban rejlik, amelyek fejlesztése szintén egy újabb lehetôséget kínál az idegenforgalom erősítésére (lásd pl. OÖFS 2008). Legfontosabb veszélyként a térségben folytatódó gazdasági hanyatlást emelhetjük ki, amelyek kihatnak a munkanélküliségre, a népesség elvándorlására. Továbbá fenyegetheti a térséget a turisztikai célú fejlesztésekből való kimaradás. A természeti értékeket a táj további degradációja veszélyeztetheti.

\section{Turizmusfejlesztési stratégiák}

\section{A Széchenyi 2020 Program hatása a turizmusra}

Salgótarján és a Karancs-Medves-vidéket érintő turizmusfejlesztésben meghatározó szerepet kap az ökoturizmus. A fejlesztések a Széchenyi 2020 program keretében valósulnak meg várhatóan 2019/2020-ban. A Széchenyi 2020 Program lényegében Európai Uniós forrást jelent, amelynek legfontosabb célja az elmaradott régiók támogatása és gazdasági felzárkóztatása. A támogatás helyi összege 101996010 Ft, amelyet a helyi önkormányzat 
használ fel. A fejlesztések célja az aktív-és ökoturizmushoz kapcsolható helyi adottságok kihasználása, turisztikai célú hasznosítása, amelynek elősegítik a vidék turisztikai versenyképességének javítását. A program középpontjában Eresztvény és a Karancs-Medves Tájvédelmi Körzet áll, ahol kiemelt hangsúlyt kapnak a természeti értékek bemutatása, a zöldturizmus fejlesztése és az aktív turisztikai kínálat bővítése. A fejlesztés fontos részét képezi az Eresztvényben található Madárpark teljes felújítása, amely során az erdei parkban élményközpontú tanösvények és interaktív turistatáblák is kialakításra kerülnek. A program érinti továbbá az infrastrukturális elemek javítását, azon belül is a pihenőpadok és a lépcsők korszerúsítését. E program keretében lezajló turisztikai fejlesztések a térségben remélhetőleg a turisták számának a növekedését eredményezi majd (web6).

\section{A Modern Városok Program hatása a turizmusra}

1388/2017.(VI:27.) Kormányhatározat Magyarország Kormánya és Salgótarján Megyei Jogú Város Önkormányzata közötti együttmúködési megállapodás rögzíti a Salgótarjánt érintő fejlesztéseket, amelynek kiemelt része a térség turisztikai vonzerejének fejlesztése. A programban 23 megyei jogú város vesz részt, célja 260 projekt megvalósítása 3400 milliárd forintból.

A megyei jogú városok közül Salgótarján fajlagosan a legmagasabb támogatást kapta, a fejlesztésekre irányuló teljes költség 90 milliárd forintot tett ki. A program célja olyan Salgótarján felmutatása volt, amelynek révén élhetőbbé, vonzóbbá, szebbé válhat a város. Egy ilyen nagy volumenú megállapodás sok elemet foglal magába, szolgálja a város fejlődését és számos lehetőséget nyújt a térség jövőjére nézve.

A kormányzati támogatást élvezve Salgótarján turisztikailag is fejlődési pályára állhat. A regionális fejlesztési tervekre irányuló támogatás 22 milliárd forintos összeg, a turisztikai ügynökség jóváhagyásával. A Modern Városok Program kiemelt része az infrastruktúra fejlesztése. Ide tartozik a 21-es számú fóút M3 autópálya és Salgótarján közötti útszakaszának 2x2 sávos bővítése, valamint Salgótarjánt elkerülő négysávos út kiépítése egészen a szlovák országhatárig. A program keretében a városközpont és a fơtér és a helyi tömegközlekedés korszerúsítése (elektromos tömegközlekedés) is fontos szempont. A támogatás érinti a térség iparának és gazdaságának a fejlesztését is. Az öblösüveggyártás fejlesztésére 4,5 milliárd forint tervezett összegú támogatás jut, valamint zöldmezős ipari üzemek kialakítására is jelentős összeget fordítanak. A Modern Városok Program fejlesztései jelentősen hozzájárulnak a térség turizmusának élénkítéséhez (web7).

\section{Empirikus kutatás a terület turisztikai helyzetének feltárására}

\section{A kutatás módszertani háttere}

A primer kutatásunk alapvetően két módszerre épült. Kutatásunkat egyrészt egy 2019. márciusi online kérdőívre alapoztuk, amelynek meghatározó célcsoportja a salgótarjáni lakosság volt. A kérdőív nemcsak a helyi lakosságot célozta meg, hanem mindazokat, akik rendszeresen járnak a térségbe és rálátásuk van Salgótarjánra és vidékére. A kérdőív online feltöltése előtt próbakitöltést végeztünk. A résztvevők megkérdezésére 2019 februárjában és márciusában került sor, összesen 200 fő töltötte ki online formában a kérdőívet. A kérdőív kitöltése önkéntes volt és 16 zárt, illetve nyitott végú kérdést tartalmazott. A kutatás másik részét egy helyi szakértővel végzett félig strukturált mélyinterjú adta. A személyes interjút a Novohrad-Nógrád Geopark Eresztvényi Látogatóközpont irodavezetőjével készítettük. 


\section{Kutatási eredmények}

A válaszadók kor szerinti összetétele

A válaszadók 32\%-a a 18-29 éves korosztályhoz tartozott (3.ábra). Ez tulajdonképpen hír abból a szempontból, hogy Salgótarjánban évról évre az egyik legnagyobb probléma a fiatalok elvándorlása. A fiatalok magasabb aránya a kitöltők között talán arra enged következtetni, hogy a helyi fiatalok valamilyen szinten szívükön viselik a város és a környék sorsát. Nem reprezentatív eredményeinkben tehát a fiatal felnőttek válaszai tekinthetők mérvadónak. Második legnagyobb arányban (23,5\%) a 40-49 év közöttiek adtak választ a kérdéseinkre (3. ábra). A 200 fős mintában a nők aránya jóval magasabb volt (64\%).

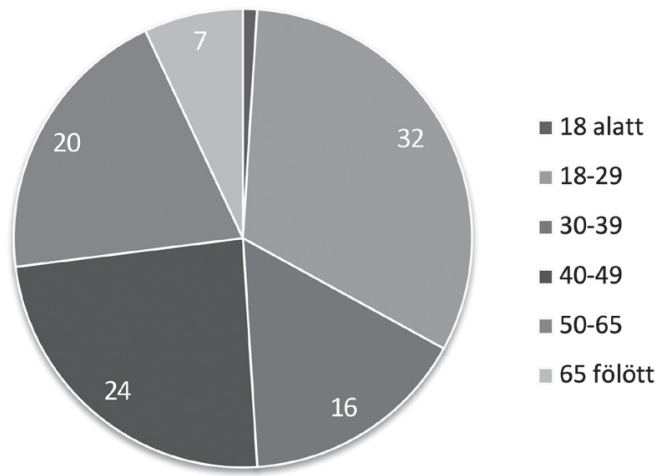

3. ábra A válaszadók kor szerinti összetétele (\%) / Figure 3 Age distribution of respondents (percent) Forrás/Source: saját felmérés/own survey

A kérdőíves kutatásunk célcsoportja a helyi lakosság, valamint sűrűn a térségbe látogatók voltak. A kutatásban résztvevők 60\%-a Salgótarjánban született, helyi lakos volt. Ôk azok, akik a legjobban belelátnak a térség mindennapjaiba, értékelni tudják a vidék turizmusát. Második legnagyobb arányban (25\%) szerepeltek azok, akik nem salgótarjáni lakosok, de rendszeresen járnak a térségbe. Kisebb részesedése volt azoknak, akik több mint 5 éve élnek a városban és környékén (11,5\%), vagy az elmúlt 5 évben költöztek a térségbe (3,5\%). Jellemző volt, hogy inkább a felsőfokú végzettséggel rendelkezők töltötték ki a kérdőívet (36\%), de a középiskolai végzettséggel rendelkezők aránya is számottevő volt (35,5\%) (4. ábra).

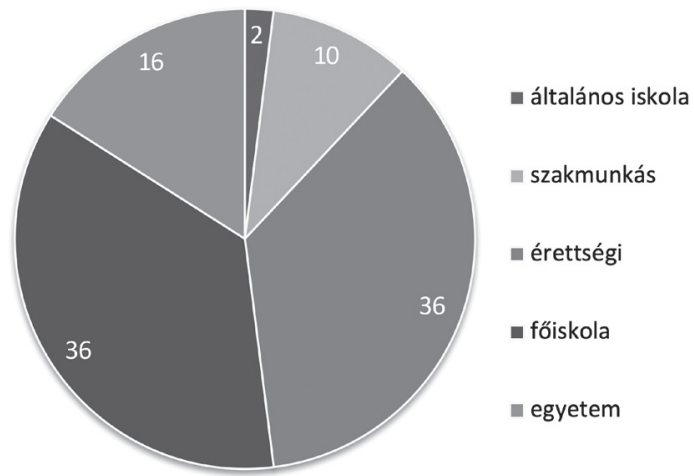

4. ábra A válaszadók iskolai végzettség szerinti megoszlása (\%) Figure 4 Distribution of respondents by educational attainment (percent) Forrás/Source: saját felmérés/own survey 
A térség idegenforgalmi helyzetének megitélése

Salgótarjánt a megkérdezettek 59,5\%-a ismeri nagyon jól. Ez azt mutatja, hogy a város attrakcióit a megkérdezettek több mint fele jól ismeri. A válaszadók többsége (55\%) úgy ítéli meg, hogy stagnál a térség idegenforgalma. A fejlődés megítélése nagyon polarizált, mindössze $1 \%$ különbség van a fejlődést vagy visszaesést érzékelők aránya között. A megkérdezettek 22\%-a nyilatkozott úgy, hogy a térség turizmusa fejlődő tendenciát mutat. A nyitott kérdésre adott válaszok alapján többen említették, hogy az idegenforgalom erôsödése elsősorban a Novohrad-Nógrád Geopark Látogatóközpontnak és szervezett, aktív programjainak köszönhető. Pozitív tendenciaként értékelték a bakancsos turizmus fejlődését is, ugyanis a természeti kincsekben gazdag környezet az utóbbi évek során több, legfőképpen természetjáró turistát vonz a vidékre. Nem véletlenül, hiszen egyre több kitáblázott turistaút, tanösvény látogatható a környéken. A térségre a legnagyobb turistaforgalmat az ökoturizmus hozza, ezáltal meghatározó turisztikai formáját képezi a helyi idegenforgalomnak (SKTK 2009).

A válaszadók között akadtak olyanok, akik a turizmus helyzetét negatívan látják. A válaszadók 23\%-a vélekedik az idegenforgalom visszaeséséról. A vidék egyik legnagyobb hiányossága a turizmus, a turisztikai kínálat alacsony színvonalú. Szerintük a szálláshelyek, a vendéglátó- és szórakozóhelyek, a szervezett rendezvények, programok hiánya, valamint a szolgáltatások alacsony színvonala felelős az idegenforgalom visszaeséséért.

\section{A szálláshelykínálat megítélése}

A helyi szálláshelykínálatról alkotott általános vélemény elszomorító, lévén a kérdőívet kitöltők 36\%-a teljes elégedetlenségről számolt be. Jelenleg a megyei jogú város központjában nem található megfelelő színvonalú kereskedelmi szálláshely, ami megnehezíti a több napos tartózkodást. Csupán kisebb vendégházak, apartmanok, fogadók várják az ide látogatókat. Pozitív példaként említhetôk a Karancs-hegység lábánál, a Medves fennsík peremén található kétcsillagos Medves Hotel, valamint a Salgón, természetvédelmi területen, az erdő közepén elhelyezkedő háromcsillagos Salgó Hotel. A szállások USP-je a hegyvidéki környezet, célcsoportjuk elsősorban az aktív turisták.

Salgótarján egykor virágzó ipari város volt. 1964. április 4-én nyitotta meg kapuit a megyeszékhely legemblematikusabb hétemeletes épülete, a Karancs szálló (7. kép). A város jelképeként számon tartott szálláshely a kor legszebb és legmodernebb szállodája volt Salgótarján központjában, amely máig meghatározza a városközpont látképét. A gazdasági visszaesés az 1970-es években érte el a nógrádi megyeszékhelyet, a rendszerváltozás pedig gyakorlatilag tönkre tette a salgótarjáni gazdaságot. Bezártak a gyárak, a bánya, leépült a bányára épült ipar és rengetegen veszítették el munkájukat a városban. A társadalmi és gazdasági hullámvölgy elsodorta a Karancs szállót is. Kezdeményezések ugyan voltak a szálló korszerúsítésére és felújítására, de a szálló még mindig üresen áll a város fő terén, csend uralja, hotel jellegét már régen elveszítette (web8).

\section{A térség turizmusmarketingjének értékelése}

A turizmusmarketinget elsősorban a személyre szabott szolgáltatások iránti növekvő igény hívta életre. Feladata, hogy a folyamatosan változó igényekre hatékonyan reagáljon, s hozzájáruljon ahhoz, hogy egy adott desztinációban megfelelő mennyiségú és minőségú vendégkör tudjon kialakulni (KozMA G. 1995; LőRINCZ K.-SUlYOK J. 2017). A turizmusmarketing tehát fontos részét képezi a turizmus fejlesztésének. A turizmusmarketing eszközei gyakorlatilag azonosak a hagyományos marketing eszközökkel, egyik legfontosabb módszere az imázsépítés. A turisztikai imázs egy viszonylag innovatív módszer, amely fontos szerepet játszik a desztináció menedzsment hatékonyságának növelésében, egy adott 


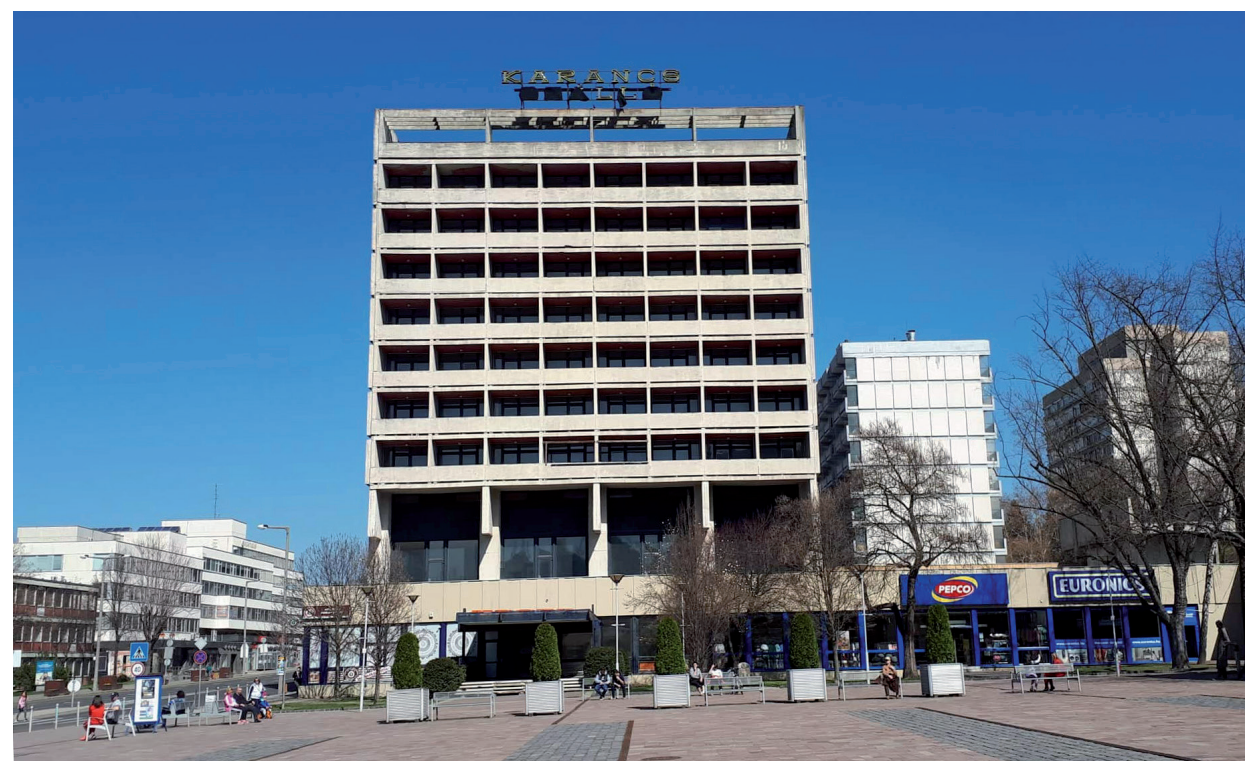

7. kép A Karancs szálló üresen álló épülete Salgótarjánban Photo 7 The empty standing Karancs Hotel in Salgótarján Forrás/Source: N. MOLNÁR

desztináció fejlesztésében és a versenyképességet is alapvetően befolyásolja. A Turisztikai Desztinációs Menedzsment célja, hogy folyamatos fejlődést indukáljon egy adott térségben a helyi turizmusban érdekelt szervezetek, egyesületetek és önkormányzatok összehangolt működésével. A Salgótarjáni Helyi Turisztikai Desztinációs Menedzsment Közhasznú Egyesület 2009-ben alakult meg. Jelenlegi tagjai önkormányzatok, kulturális bemutatóhelyek, sport-és szórakoztató szolgáltatók, szállás-és vendéglátóhelyek, civil egyesületek és egyéb szolgáltatók (web9).

A válaszadók $82 \%$-ának véleménye szerint a város turizmusmarketing tevékenység nem megfelelő. Pedig jelentős potenciál van Salgótarján és környékének turizmusában, ami kitörési lehetóséget biztosíthatna a városnak és hozzájárulhatna ahhoz, hogy országos szinten népszerűbb úticéllá váljon a környék. Az egyedülálló tájkép, a hegyek közelsége meghatározó rugója lehet a fejlesztésnek, ugyanis a térség olyan természeti, domborzati adottságokkal rendelkezik, amit a vidéknek ki kellene aknáznia. A városról alkotott negatív képet ezáltal felválthatná egy pozitív imázs és növelhetné az aktív kikapcsolódásra és a pihenésre vágyó vendégek számát.

A kérdőív résztvevői a marketingtevékenység javítására több és színvonalasabb rendezvényt szorgalmaznak. Megemlítették a valaha országos hírú rendezvényeket, amelyeket ezen a vidéken rendeztek és tömegeket vonzottak a térségbe. Ilyen volt például a Salgó Rallye, amely Magyarország egyik legrégebbi és leghíresebb raliversenye, vagy a Salgótarjáni Ugrógála, amely a nógrádi megyeszékhely legjelentősebb nemzetközi sportés turisztikai rendezvénye volt.

\section{Legvonzóbb turisztikai termékek}

Kérdőívünkben felmértük, hogy amelyek azok a turisztikai attrakciók, amelyek leginkább vonzzák a turistákat a vidékre. A kérdésre adott válaszban több lehetőséget is meg lehetett jelölni, a 200 válaszadó átlagosan három attrakciót jelölt meg a kérdőívben. A vá- 
laszadók egyértelmúen a történelmi és a természeti értékeket jelölték meg a terület fő vonzerőiként. A válaszadók szerint a környék legfontosabb vonzerői a Somoskői vár (a válaszadók 66\%-a említette meg) és Salgó vára (63\% jelölte meg). Kiemelkedő volt az Ipolytarnóci ősmaradványok, mint vonzeró megjelölése $(58,5 \%)$ (5. ábra).

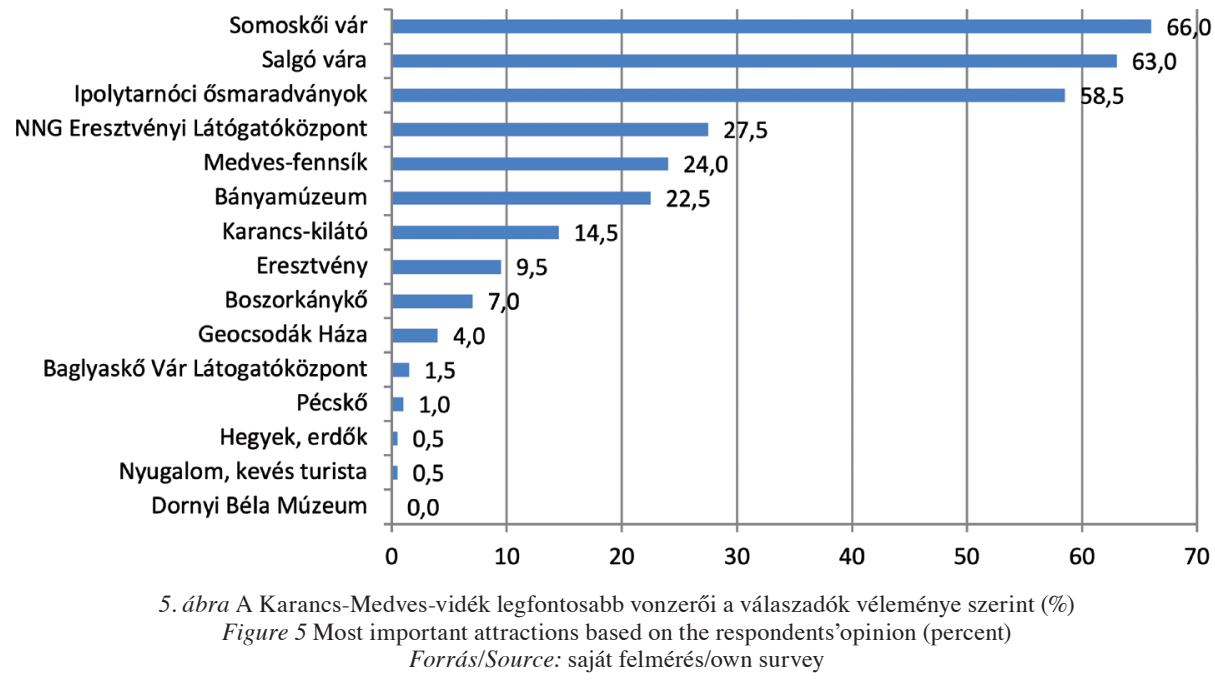

Turisztikai szempontból jelentős potenciál van a már említett Novohrad-Nógárd Geopark Látogatóközpont üzemeltetésében is (27,5\%). Nemzetközi pályázatok vannak, amelyek a geopark múködését segítik, de a turizmus fellendítését a Modern Városok Programtól is várják. A turizmus növekedésében a geopark nagy részt vállal és az utóbbi időben a térség egyik fó turisztikai attrakciójává vált. A geopark Eresztvényi Látogatóközpontja 2018-ban összesen 30 rendezvényt bonyolított le és mintegy 36 ezer látogatót fogadott. A programok közül kiemelhetjük a Geopark Családi Napot és az Olympus Medvesi Fotós Maratont. A Novohrad-Nógrád Geopark térségi, hazai és nemzetközi kapcsolatokban, együttmúködésekben gazdag, az UNESCO Globális Geoparki Hálózat tagja. A helyi szakemberek szerint a vidékre érkező turisták száma várhatóan növekedni fog, további ökoturisztikai szolgáltatások jelennek meg és az ökoturizmus erősödni fog. 2018-ban napi rendszerességgel keresték fel szlovák turisták és csoportok a látogatóközpontot, valamint megjelentek a cseh és lengyel turisták is a térségben. A jövőben a látogatóközpont kifejezetten a medvesi turisztikai programok szervező központjává válhat. A jövőbeli fejlesztések között említhetjük a jelenleg kidolgozás alatt álló geoparkkártya, amellyel az itt megszálló turisták különféle kedvezménnyel vehetnék igénybe a térség szolgáltatásait. A válaszadók szerint a jelentősebb természeti vonzerők között említhetjük még a Medves-fennsíkot (24\%) és a Karancs-kilátót $(14,5 \%)$. Az ipartörténeti vonzerók közül a Bányamúzeumot emlehetjük ki (a megkérdezettek 22\%-a említette). Meglepő, hogy a Dornyay Béla Múzeum egyetlen jelölést sem kapott, ami jelzi, hogy a múzeum jelenleg nem szerepel a salgótarjániak mentális térképén.

\section{A turizmusfejlesztés lehetséges hatásai}

A válaszolók szerint Salgótarjánban és a Karancs-Medves-vidéken a turizmus fejlődése magával hozná az infrastruktúra fejlődését, ami hozzájárulna a helyi lakosság életminőségének javulásához. A turizmus fellendülése anyagi szempontból is fontos lenne, hiszen 
több munkalehetőséget eredményezne a városban, ami többek számára biztosítana megélhetést és javítaná az életkörülményeket. A magas munkanélküliség súlyos probléma az észak-magyarországi régióban, akárcsak az elöregedő népesség és a hátrányos helyzetúek, mélyszegénységben élők magas aránya. Az idegenforgalom mindenképpen pozitív hatással bírna a foglalkoztatottságra, a növekvő munkahelykínálat megakadályozhatná a térségből való nagyszámú elvándorlást is. A turizmus fejlesztése fellendítené és formálná az adott térség imázsát is. Az imázs növekedésével a város és környezete élhetőbbé, vonzóbbá és többek számára ismertté válhatna. Negatív hatások elsősorban a környezeti és társadalmi tényezőkre vezethetôk vissza. A válaszadók szerint az árak emelkedése és az illegális szemétlerakás problémája hatványozottan jelentkezik a térségben, problémája. Potenciális veszélyforrás lehet a turisztikai terhelés helyi lakosságra gyakorolt mértéke is. Éppen ezért Salgótarjánnak és a Karancs-Medves-vidéknek fenntartható turisztikai fejlesztésre van szüksége helyi erőforrások felhasználásával és természeti erőforrások megőrzésével.

\section{Következtetések és összefoglalás}

Megállapíthatjuk, hogy a vizsgált területen a turizmus fejlesztése mindenképpen indokolt, ugyanis a vidék gazdasági versenyképessége gyenge, az idegenforgalom pedig hátrányos helyzetben van. Salgótarján és a Karancs-Medves-vidék gazdag turisztikai kínálata önmagában nem elegendő a versenyképes turizmushoz, ugyanis számos területen fejletlenség és elmaradás jellemzi a területet. A terület és általában a hátrányos helyzetû területek turizmusfejlesztésének legfontosabb lépése a szupra- és infrastruktúra fejlesztése. Hiába adott számos kulturális, történelmi emlék, geológiai képződmény, világörökségi helyszín és sok más korábban már felsorolt vonzerő, ha a szupra- és infrastruktúra nem megfelelő. Legnagyobb probléma a nem megfelelő szálláshely-szolgáltatás, a fejletlen infrastruktúra és a színvonalas rendezvények, programok hiánya. A kutatási eredmények egyértelmúen a térség turisztikai fejlesztésének fontosságára, szükségességére és a fejlesztés iránti igényekre mutattak rá.

Fontos célkitűzésnek kell lennie, hogy a turisztikai attrakciókhoz kapcsolódó szuprastruktúrát fejlesszék a városban és a térségben (pl. színvonalas szórakozó- és vendéglátóhelyek létesítését hosszabb nyitvatartási idővel). Salgótarján és környékének turisztikai fejlesztése esetén nagyobb hangsúlyt kellene fektetni a vendéglátásra. Turizmus nincs vendéglátás nélkül, azonban vendéglátás sincs turizmus nélkül. Megállapíthatjuk, hogy a szuprastruktúra mellett elengedhetetlen a jelenleg hiányos és rossz állapotban lévô infrastruktúra fejlesztése is. Szálláshelyekre van szükség mind mennyiségi, mind minőségi értelemben (válaszadók 54\%-a javasolta). A megkérdezettek nagyon fontosnak tartják a városközpontban egy színvonalas kereskedelmi szálláshely létrehozását (pl. négy csillagos wellness szállodának a városközpontban), amely lehetőséget biztosítana több napos itt tartózkodásra. Többen felvetették az egykori Karancs Szálló átalakítását, hiszen jelenleg elhanyagoltan, üresen áll a város centrumában. Valószínúleg nagy változást eredményezne a vidék idegenforgalmában és újra a város jelképévé válhatna, ha teljes körúen felújítanák. A tágabb környéket, a Karancs-Medves-vidéket egyedülálló hegyek, völgyek, erdők, fennsíkok veszik körül, így ebbe a zöld környezetbe nem lenne szerencsés a tömegturizmust vonzó wellness szállodák kialakítása. Jobb lenne az Eresztvényben található Dornyay Turistaház rekonstrukciója, amely gyönyörű fekvése miatt kiváló erdei panzióként várhatná az ide látogatókat. a minőségi, adhatna helyet. A szupra- és infrastruktúra fejlesztése mellett mindenképpen szükség van attrakciófejlesztésre és a térségben múködő turisztikai szervezetek és vállalkozások szorosabb együttmúködésére. 
Fontos a városi strandfürdő fejlesztése is (válaszadók 34\%-a javasolta). Jelenleg a szerény Tóstrand egy úszómedencével és egy pancsolóval rendelkezik. A városlakók kezdeményeznék a korszerúsítést, ugyanis úgy gondolják, hogy egy múködő, tömegeket vonzó strand nagymértékben tudná szolgálni a város idegenforgalmának fellendülését. A felmérésből az is kiderült, hogy megkérdezettek nem tartják kielégítőnek a turisztikai szervezetek közti együttmúködést, valamint a turizmus fejlesztésének önkormányzati támogatását.

A turizmus fejlesztésében meghatározó szerepet játszik a rendelkezésre álló turisztikai potenciál jobb és komplexebb kihasználása. Salgótarján és a Karancs-Medves-vidék természeti adottságai rendkívül kedvezőek és turisztikai kínálata kiemelkedő (KARANCSI Z. et al. 2009). A kérdőív válaszadói közül többen azon a véleményen vannak, hogy a NovohradNógrád Geopark Látogatóközpont kezdeményezései jó irányba haladnak, ugyanis egyre több látogatót és turistát vonzanak a vidékre. 2018-ban a salgótarjáni Tourinform irodánál volt a legnagyobb látogatói létszámnövekedés az országban, amely a Novohrad-Nógrád Geopark Látogatóközpontjában múködik. A Novohrad-Nógrád Geopark és folyamatosan bővülő szolgáltatásai iránt évrôl évre nő a kereslet. A látogatóközpontban egyre inkább előtérbe kerülnek az ökoturizmus szolgáltatásai, amelyek a jövőbeli a fejlesztéseket tekintve jelentős potenciált hordoznak Salgótarján és a Karancs-Medves-vidék turizmusában. A geopark mintájára több, szervezett, egyedi programra lenne igény a természeti és környezeti látványosságok bemutatására. Jó példaként említethetjük a Medvesi Fotós Maratont, amelynek keretében 48 órán át készülhetnek fotók a Medves legszebb részeirôl. A határon túli kapcsolatok megerösitése és tematikus utak szervezése a turizmusfejlesztés egyik fontos pillére lehet a jövóben (KovÁcs I. 2014).

A helyi eróforrásokon és adottságokon alapuló színvonalas rendezvények és programok szervezése elengedhetetlen a továbbfejlődéshez. Kutatási eredményeink alapján ezeknek a város turizmusfejlesztési célkitúzései között feltétlenül szerepelnie kell (a válaszadók $58 \%$-a javasolta). A színvonalas rendezvények és programok nemcsak a helyi turizmus színvonalát, hanem a lakosság életszínvonalát is emelnék.

A térség lemaradása nemcsak a turizmus területén jelentős, a probléma sokkal összetettebb. A terület helyzete viszont orvosolható lenne, amelynek egyik eszköze a helyi turizmus fejlesztése lehetne. A vidék turizmusában a fenntarthatóságot kell erösíteni, ugyanis e nélkül elveszti a táj az értékét, az itt kialakult változatos tájkép és élővilág pedig meghatározó természeti erőforrás a turizmusban (DREXLER Sz. et al. 2003). A turizmus fejlesztésében évek óta mindenki reménykedik, a turizmust érintő kezdeményezések többsége azonban nem valósult meg, hanem megrekedt a tervezés szintjén. Annak érdekében, hogy a turizmus kifejtse a térségre gyakorolt gazdaságfejlesztő hatását elengedhetetlen a helyi, elsösorban természeti értékekre épülö turisztikai attrakciók, szolgáltatások, szálláshelykinálat fejlesztése és bővitése és az ezek megvalósításához szükséges turizmusmarketing tevékenység.

Bár a turizmus hatékony imázsformáló erővel rendelkezik, a fejlesztések hosszú távú stratégiát igényelnek, így a térség fejlődése is hosszú távú folyamat, rövidtávon csodákat nem várhatunk. Mindenesetre a lehetőségek adottak, hogy Salgótarján és a Karancs-Medvesvidék a fejlődés útjára álljon és turisztikailag versenyképessé váljon. A terület sikeressége a döntéshozókon, a helyi gazdasági szereplőkön, civil szervezeteken és a lakosokon egyaránt múlik. A turisztikai potenciál jobb kihasználása megnyithatná az utat egy fenntartható lassú turizmus (slow tourism) elótt, amely hozzájárulhatna ahhoz, hogy a Karancs-Medvesvidék reális alternatívát kínáljon az ország overturizmussal fenyegetett desztinációival szemben. Ezt az egyelőre kiaknázatlan lehetőséget jól tükrözi a geopark vezetőjének optimizmust sugárzó szemlélete is: „Salgótarjánban születtem, sajnos és szerencsére”. 


\title{
Köszönetnyilvánítás
}

A tanulmány elkészítését és megjelenését az NKFIH/OTKA K128717 sz. projekt támogatta. Köszönjük HoRvÁTH GERGELY értékes szakmai észrevételeit és javaslatait!

\author{
MOLNÁR NóRA \\ BGE KVIK Turizmus Tanszék, Budapest \\ molnar.nola@gmail.com
}

EGEDY TAMÁS

CSFK Földrajztudományi Intézet, Budapest - BGE KVIK Turizmus Tanszék, Budapest egedy@gmx.net

\section{IRODALOM}

Archer B.-CoOper, C.-Ruhanen, L. 2005: The positive and negative impacts of tourism.- In: TheOBALD, W. (ed): Global tourism: The Next Decade. - Butterworth-Heinemann, Oxford. pp. 79-102.

Benckendorff, P.-Edwards, D.-Jurowski, C.-Liburd, J. J.-Miller, G.-Moscardo, G. 2009: Exploring the future of tourism and quality of life. - Tourism and Hospitality Research 9. pp. 171-183.

Boros L. (2002): A határmentiség hatása a turizmusra. - In: SzÓNOKYNÉ, A. G. (szerk.) Határok és az Európai Unió. - JATEPress, Szeged, pp. 141-145.

Chaperon, S.-Bramwell, B. 2013: Dependency and agency in peripheral tourism development. - Annals of Tourism Research 40. pp. 132-154.

Csüllög G.-HoRvÁth G. 2010: Salgótarján bányász kulturális örökségének hasznosítási stratégiája. - ReSOURCE Central Europe Project 1CE084P4, - Salgótarján Megyei Jogú Város, Budapest. 51 p.

DÁvid L.-KovÁcs B.-TóTH G. 2009: A turizmus szerepe az Észak-Magyarországi régióban: a munkaerôpiac és a makrogazdasági teljesítmény összefüggései. - Észak-magyarországi Stratégiai Füzetek 4. 1. pp. 16-27.

DE KADT, E. (ed) 1979: Tourism-Passport to Development? Perspectives on the Social and Cultural Effects of Tourism in the Developing Countries. - Oxford University Press, Oxford. 384 p.

DreXler Sz.-Horváth G.-KARANCsi Z. 2003: Turizmus, természetvédelem és tájhasznosítás kapcsolata egy nógrádi kistájrészlet példáján. - Földrajzi Közlemények 127. 1-4. pp. 45-61.

Gelsei S.-Goldmann R.-Kecskeméti S.-Király L.-Kulcsárné K.A.-Ocsenás R.-Szilágyiné B.A. 2017: Helyzetértékelés - Észak-Magyarországi régió. - Észak-Magyarországi Regionális Fejlesztési Ügynökség Kht., Miskolc. 67 p.

HÁgen A.-HoRváth D.-STromp M. 2013: Hogyan mozogtak az ipolytarnóci ősállatok? - Természet Világa. pp. 87-88.

Hauenschield V.-I Grub P. D. 1978: International Tourism as a Factor in Economic Development for the L. D. C.'s. - Journal of Economics Development 3. pp. 153-172.

Horváth G. 2009: Bányászati örökség, környezetgazdálkodás és geoturizmus. - In: FriSNYÁK S.-GÁL A. (szerk.): A Kárpát-medence környezetgazdálkodása. - Nyíregyháza-Szerencs, pp. 199-213.

Horváth G.-CsÜLlÖG G.-KARANCSI Z. 2012: A bányászati örökség és az ökoturizmus kapcsolata Salgótarján térségében. - In: FRISNYÁK S.-KóKAI S. (szerk.): Tiszteletkötet dr. Boros László főiskolai tanár 75. születésnapjára. Nyíregyháza, pp. 71-88. http://www.termeszetvedelem.hu/_user/downloads/okoturizmus/okoturizmus_strategia_X.pdf [Letöltve: 2019.03.20.]

KARANCSI Z.-HoRVÁTH G.-KISS A. 2009: A képeslap, mint a turizmusmarketing fontos eszköze; tájesztétikai vizsgálatok a Medves-térség területén. - Közép-európai Közlemények 2. 4-5. pp. 219-226.

Kiss G.-BARÁZ Cs.-GAÁLOVÁ, K.-JudiK B. (szerk.) 2007: A Karancs-Medves és a Cseres-hegység Tájvédelmi Körzet. Nógrád és Gömör határán. - Bükki Nemzeti Park Igazgatóság, Eger. 382 p.

KovÁcs I. 2014: A periférikus területek turizmusa Magyarországon - a tematikus utak mint lehetóségek. Taylor: gazdálkodás- és szervezéstudományi folyóirat 6. 3-4. pp. 248-257.

KozMA G. 1995: Városmarketing, mint a helyi gazdaságfejlesztés egyik lehetséges eszköze. - Tér és Társadalom 9. 1-2. pp. 37-54.

KSH 2014: Nógrád megye számokban 2013. - Központi Statisztikai Hivatal, Budapest. 46 p. http://www.ksh. hu/docs/hun/xftp/idoszaki/regiok/mesz/12_no.pdf [Letöltve: 2019.03.20.] 
KSH 2019: Magyarország közigazgatási helynévkönyve 2019. január 1. - Központi Statisztikai Hivatal, Budapest. 234 p.

LŐRINCZ K.-SUlYOK J. (szerk.) (2017): Turizmusmarketing. - Akadémiai Kiadó, Budapest. 357 p.

MichaLKó G. 2004: Turizmus a belső periférián: a Tiszazug és környékének turizmusföldrajzi vizsgálata. - Földrajzi Értesítő 53. 3-4. pp. 247-268.

NTS 2017: Nemzeti Turizmusfejlesztési Stratégia 2030. -Magyar Turisztikai Ügynökség, Budapest. 156 p. https://mtu.gov.hu/documents/prod/mtu_strategia_2030.pdf [Letöltve: 2019.03.22.]

OÖFS 2008: Országos Ökoturizmus Fejlesztési Stratégia. - Pannon Egyetem Turizmus Tanszék - Aquaprofit Zrt.. Veszprém - Budapest. 170 p.

PÉTER Zs. 2010: A turizmus térségi folyamatainak összefüggései, különös tekintettel az Észak-magyarországi régióra. - PhD disszertáció, Miksolci Egyetem Gazdaságtudományi Kar, Miskolc. 180 p.

PISкóTi I. (szerk.) 2006: Észak-Magyarország Régió Turizmusfejlesztési Stratégiája 2007-13. - Magyar Turizmus Rt. - RMC Regionális Marketing Centrum Kft., Miskolc. 117 p. http://www.terport.hu/webfm_send/667 [Letöltve: 2019.03.20.]

Prakfalvi P.-GaÁl L.-HoRváth G. 2007: Földtani felépítés, szerkezeti viszonyok, földtani értékek. - In: KISS G.-BARÁz Cs.-GAálová, K.-JudiK B. (szerk.) (2007): A Karancs-Medves és a Cseres-hegység Tájvédelmi Körzet. Nógrád és Gömör határán. Bükki Nemzeti Park Igazgatóság, Eger. pp. 13-42.

SAlvatoRe, R.-Chiodo, E.-FAnTini, A. 2018: Tourism transition in peripheral rural areas: Theories, issues and strategies. - Annals of Tourism Research 68. pp. 41-51.

SKTK 2009: A Salgótarjáni Kistérség Területfejlesztési Koncepciója 2008-2015. - Salgótarjáni Kistérség Fejlesztési Tanácsa, Salgótarján. 112.p. http://www.terport.hu/webfm_send/1654 [Letöltve: 2019.03.20.]

SzePESSy G. 2014: Karancs-Medves Túrakalauz. - Kornétás Kiadó, Budapest. 250 p.

SzTANó O.-HaRangi Sz. 2010: Ipolytarnóci Természetvédelmi Terület. - In: HaAs J. (szerk.) 2010: A múltunk ösvényein. Szemelvények Magyarország földjének történetéből. - Magyarhoni Földtani Társulat, Budapest, pp. 132-137.

Tájékoztató 2015: Tájékoztató Borsod-Abaúj-Zemplén megye turisztikai helyzetéről. - Magyar Turisztikai Ügynökség Zrt., Budapest. 25 p. http://www.baz.hu/content/2016junius/1606_17_turizmus_2015.pdf [Letöltve: 2019. 03. 20.]

\section{Internetes források}

webl:http://karancs-medves.blogspot.com/p/karancs-medves_28.html [Letöltve: 2019.06.13.]

web2:http://www.geopark.hu/home/mi-a-geopark [Letöltve: 2019.03.13.]

web3: http://karancs-medves.starjan.hu/cgi-bin/guestimage.html [Letöltve: 2019.07.13.]

web4: https://dornyaymuzeum.hu/muzeum/dornyay-bela-muzeumrol/ [Letöltve: 2019.08.13.]

web5: https://www.nool.hu/kozelet/helyi-kozelet/deneverek-nyestek-menedeke-az-egykori-menedekhaz-

2079997/ [Letöltve: 2019. 03. 13.]

web6:https://www.salgotarjan.hu/apps/projekt_adatlapok/top-6-1-4-16-st1-2017-00001/ [Letöltve: 2019.09.17.] web7:https://net.jogtar.hu/jogszabaly?docid=A17H1388.KOR\&timeshift=fffffff4\&txtreferer=00000001.TXT

[Letöltve: 2019.03. 17.]

web8:https://vs.hu/gazdasag/osszes/a-varos-amely-leesett-a-terkeprol-0224\#!s0 [Letöltve: 2019.08.20.]

web9:http://www.salgotarjan-turizmus.hu/hu/info/tdm/salgotarjan-helyi-tdm-kozhasznu-egyesulet/ [Letöltve:

2019. 10. 17.] 